\title{
O INEVITÁVEL ENCONTRO: POVOS KAGWAHIVA, AGENTES DO SPI E OS COMERCIANTES NO RIO
} MADEIRA

\author{
THE INEVITABLE MEETING: KAGWAHIVA PEOPLE, SPI AGENTS \\ AND TRADERS ON THE MADEIRA RIVER
}

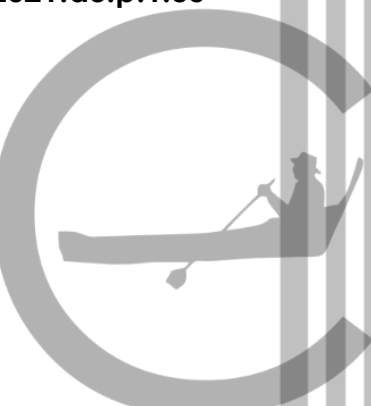

Jordeanes do Nascimento Araújo'

\begin{abstract}
Resumo
A presença do SPI nos afluentes do rio Madeira caracterizou-se como o primeiro processo de territorialização que afetou os povos Kagwahiva. Nas décadas seguintes, esses processos sofisticaram-se. A mineração, as aberturas de rodovias no interior das terras indígenas, bem como a penetração da frente agropecuária nos territórios Kagwahiva, representaram a transmutação destes processos. Nesse sentido, o Estado exerceu seu papel ao lançar mão de processos de inculcação de seus preceitos, refletidos na unidade de crença e pertencimento, lembrança sempre da intencional erradicação dos costumes nativos, da vivência do tempo e do espaço cercado pelo grande cerco de paz. É interessante frisar que as imagens do passado dos povos Kagwahiva, que inevitavelmente envolvem todos os conflitos e embates originados nos processos de territorialização orquestrados pelo poder tutelar, serviram, na contemporaneidade, como estratégias de resistência indígena. Tais imagens rememorizadas no cotidiano dos grupos Kagwahiva foram, de certa forma, práticas de luta Kagwahiva, uma espécie de "pacificação do branco", táticas de defesa do território. Não por acaso, as formas de resistência dos povos Kagwahiva não mobilizam ações apenas no nível micro, mas antes extrapolam fronteiras nacionais, indigenizando a esfera pública.
\end{abstract}

Palavras-chave: Pacificação; Kagwahiva; Regime tutelar.

\begin{abstract}
The presence of the SPI in the tributaries of the Madeira River was characterized as the first territorialization process that affected the Kagwahiva people. In the following decades, these processes became more sophisticated. Mining, the opening of highways in the interior of indigenous lands, as well as the penetration of the agricultural front in the Kagwahiva territories, represented the transmutation of these processes. In this sense, the State exercised its role by resorting to processes of inculcating its precepts, reflected in the unity of belief and belonging, always remembering the intentional eradication of native customs, the experience of time and space surrounded by the great siege of peace. It is interesting to note that the images of the past of the Kagwahiva people, which inevitably involve all conflicts and clashes originating in the territorialization processes orchestrated by the tutelary power, served, in contemporary times, as strategies of indigenous resistance. Such images recalled in the daily lives of the Kagwahiva groups were, in a way, Kagwahiva fighting practices, a kind of "pacification of the white", tactics for defending the territory. Not by chance, the forms of resistance of the Kagwahiva people do not mobilize actions only at the micro level, but rather go beyond national borders, indigenizing the public sphere.
\end{abstract}

Keywords: Pacification; Kagwahiva; Guardian regime.

\footnotetext{
${ }^{1}$ Possui doutorado em Ciências Sociais pela Universidade Estadual Paulista- UNESP (2019). Antropólogo, atualmente é Professor Adjunto II da Universidade Federal do Amazonas/Campus de Humaitá. E-mail: jordeanes@ufam.edu.br
} 


\section{Povos Kagwahiva, agentes do SPI e os comerciantes}

As narrativas Tupi-Kagwahiva sobre o tempo do seringal, sobre o tempo do patrão, são carregadas de performances a respeito do encontro entre os comerciantes, os agentes do SPI e os indígenas.

$\mathrm{O}$ trabalho no seringal quase destruiu a cultura Parintintin. Nesse tempo, meu pai contava que ouviu do meu avô que a gente trabalhava demais para a família dos Lobo. Aí com o tempo o Parintintin foi se separando e se espalhando. Uma parte foi pro Calama, outra ficou por aqui, próximo do seringal Três Casas, perto do igarapé Traíra. Outro grupo foi pra o Uruapiara. A gente trabalhava e não conseguia pagar as contas. Todo mês a dívida era maior (informação verbal ${ }^{2}$ ).

As estratégias do SPI para tentar apaziguar os conflitos entre os povos indígenas e os regionais no rio Madeira iniciaram-se em 1913. Tais estratégias não se efetivaram. Na prática, o projeto inicial de pacificação ficou restrito aos gabinetes da inspetoria do SPI, em Manaus.

Nesse mesmo período, o seringalista Manoel Lobo deu fôlego a novos processos de territorialização para o sul e sudeste do rio Madeira, chegando, dessa forma, até a Bacia do rio Maicy, com o objetivo de exploração da sorva, borracha, óleo de copaíba e castanha. Simultaneamente, o encarregado da família Sizino Monteiro, José Ferreira Duarte, se deslocou do Seringal Paraíso para as cabeceiras do rio Marmelo e do rio Maicy, agravando a disputa pelo poder econômico no rio Madeira.

No início de 1921, por inciativa do Marechal Rondon, o Coronel João Portatil foi enviado para as margens do rio Madeira, acompanhado por trabalhadores do seringalista Manoel Lobo, montando, ali, uma expedição que objetivava encontrar as malocas dos Tupi-Kagwahiva. Essa iniciativa encontrou malocas abandonadas, mas apenas na bacia do rio Maicy. E no final da expedição, conforme Nimuendaju ${ }^{3}$, João Portatil "caiu num fojo, na entrada de uma maloca abandonada, feriu-se gravemente e só alcançou a margem do Madeira carregado pelos companheiros que dali em diante não quiseram mais acompanha-1o".

No mesmo ano, outro encarregado do SPI, atracou às margens do rio Marmelos, com o objetivo de realizar um levantamento topográfico e instalar um posto de atração indígena na bacia do rio Maicy. Tratava-se do capitão E.S. Amarantes, genro do Marechal

\footnotetext{
${ }^{2}$ Narrativa coletada com M. Parintintin, outubro de 2016

${ }^{3}$ Nimuendaju, Curt. Os índios Parintintin do rio Madeira. Jounal de la Société des Americanistes de Paris. p. 59, 1924.
} 
Rondon. Amarantes construiu um posto indígena junto ao Povo Pirahã, num esforço para atrair os Tupi-Kagwahiva.

Segundo Nimuendaju, a estratégia do Capitão Amarantes jamais poderia dar certo, pois o

Posto estava levantado num lugar onde a presença Mura-Pirahã, inimigos mortais dos Parintintin, jamais permitia a estes achegar-se a ele despreocupadamente (...). Em dois anos de existência daquele posto, jamais um seu encarregado conseguiu ver um só Parintintin ${ }^{4}$.

Com a decadência do período da borracha, no início do século $\mathrm{XX}$, a castanha se transformou no principal produto financeiro para os seringalistas nos rios do Amazonas. Os rios Canumã, Abacaxis e Marimari, terra dos Munduruku, passaram a ser cobiçados por aventureiros, comerciantes e seringalistas, pela descoberta de grandes castanhais nas margens destes rios. A partir de 1925, o hectolitro da castanha custava, no mercado internacional, 100 mil réis. O rio Madeira e principalmente seus afluentes, o rio Maicy e o rio Marmelos, possuíam grandes quantidades de castanhais em suas margens.

Em meados de 1921, Bento de Lemos, inspetor do SPI, viajou pelos seringais do rio Madeira com o objetivo de mapear os conflitos existentes entre os povos indígenas e os regionais. Ao relatar os diversos conflitos, Bento de Lemos descreveu que a maioria ocorria em áreas de grandes castanhais. Antes da execução do plano de pacificação, Manoel Lobo havia sido nomeado por Alípio Bandeira como delegado de índios do rio Madeira. Segundo Bento de Lemos, o delegado era uma figura meramente honorífica, tratando-se, inclusive, de um cargo não remunerado.

São apenas representantes da inspetoria em lugares onde não há estabelecimentos mantidos por esta, para os efeitos de vigiar pelos índios, zelando pela defesa de suas vidas, liberdade e propriedade ${ }^{5}$.

Em outro relatório do SPI, de $1929^{6}$, a inspetoria identificou os delegados como representantes de direitos opostos dos indígenas. Segundo Rocha Freire ${ }^{7}$, "eram seringalistas, comerciantes, burocratas que só defendiam os índios quando seus interesses

\footnotetext{
${ }^{4}$ Nimuendaju, Curt. Os índios Parintintin do rio Madeira. Jounal de la Société des Americanistes de Paris. p. 59-60, 1924.

${ }^{5}$ LEMOS, Bento Martins Pereira de. Relatório encaminhado ao Diretor do SPI, Sr. Dr. José Bezerra Cavalcante. Referente aos serviços da IR1 nos exercícios de 1925 (filme 33, planilha 396, p. 2-44); 1928 (filme 33, planilha 396, p-4-24); 1930 (filme 33, planilha 396, p.02- 12), Rio de Janeiro, Museu do Índio. ${ }^{6}$ LEMOS, Bento Martins Pereira de. Relatório do Inspetor referente aos trabalhos referente aos trabalhos realizados no exercício de 1928. Inspetoria do Amazonas e Acre. Manaus: MAIC 1929.

${ }^{7}$ FREIRE, Carlos A. da Rocha. O SPI na Amazônia: política indigenista e conflitos regionais (19101932). Rio de Janeiro: Museu do Índio, 2009.
} 
pessoais não fossem prejudicados". Na maioria dos casos, entre os diferentes rios da Amazônia, ocorriam inúmeros conflitos entre os agentes do SPI e os seringalistas. Em um caso específico, no rio Solimões, a estratégia do servidor do SPI foi negociar a farinha produzida pelos Ticuna pagando-os em dinheiro, com preço acima daquele pago pelo patrão. Com isso, os Ticuna criaram uma forma de resistência contra a opressão exercida mediante o sistema de endividamento do barracão ${ }^{8}$.

Em outro extremo, Edgar Penha, ex-servidor do SPI, atuou junto aos WaimiriAtroari, passando a persegui-los, cobiçando suas terras e seus castanhais. Penha massacrou e envolveu os indígenas em confrontos violentos, afundando embarcações, perseguindo o chefe indígena da área, conforme escreveu Rocha Freire ${ }^{9}$. Joaquim Pessoa Sobrinho, também ex-servidor do SPI, tentou apossar-se das terras dos Munduruku desde 1914. No mesmo sentido, Luiz José Soares perseguiu e torturou os Munduruku para forçálos a abandonarem suas terras.

No rio Madeira, Manoel Lobo era o comerciante mais bem sucedido na exploração das terras tradicionalmente pertencentes aos Tupi-Kagwahiva. Em 1910, este seringalista estendeu suas explorações até os limites da bacia do rio Maicy. Sua estratégia inicial fora não entrar em conflito armado com os indígenas, mas sim tentar "pacificá-los" para uma dupla exploração, a saber, força de trabalho e controle dos recursos naturais.

Nesse contexto, a presença do SPI ajudou-o na montagem de uma estratégia que garantisse a efetivação de seus interesses concernentes às terras indígenas e suas riquezas naturais. No entanto, a presença de Curt Nimuendaju no processo de pacificação parece ter ofuscado os planos políticos de Manoel Lobo.

Em outubro de 1921, cheguei em Três Casas, onde tive de refutar outro plano mal elaborado de Manoel Lobo, que queria que se fundasse o posto de pacificação nos limites dos seringais delle. Resolvi procurar um lugar apropriado no Maicy-Mirim e para este fim entrei com uma dúzia de homens em Pádua, avançando em rumo sudeste, passei no segundo dia, as ultimas barracas de seringueiro, queimadas pelos Parintitin e cheguei no quarto dia no igarapé Traíra, afluente do Alto Maicy-Mirim. Desci pelo igarapé e pelo dito rio e escolhi na margem direita dele, junto da embocadura de um pequeno afluente, o lugar para o futuro posto de pacificação. Já Manoel Lobo e a gente do Paraíso tinham acampado neste lugar, dando-lhe o nome de "Nove de Janeiro" e ainda se via lá os restos do ranchinho queimado pelos Parintintin ${ }^{10}$.

\footnotetext{
${ }^{8}$ OLIVEIRA FILHO, João Pacheco de. Ensaios de Antropologia Histórica. Rio de Janeiro: Editora da UFRJ, 1999.

${ }^{9}$ FREIRE, Carlos A. da Rocha. O SPI na Amazônia: política indigenista e conflitos regionais (19101932). Rio de Janeiro: Museu do Índio, 2009.

${ }^{10}$ NIMUENDAJU, Curt.Os índios Parintintin do rio Madeira. Jounal de la Société des Americanistes de Paris. p. 60, 1924
} 
Qual o interesse de Manoel Lobo no processo de "pacificação" dos TupiKagwahiva? Qual o contexto político-econômico no qual se encontravam os seringalistas do rio Madeira? Quais os interesses do SPI ao sedentarizar os grupos domésticos Kagwahiva nos postos de pacificação?

Para responder a tais questões é mister que eu ponha a nu a trajetória de atuação de Manoel de Souza Lobo como delegado de índios do rio Madeira. Nascido no lago do Uruapiara (terra imemorial dos Kagwahiva), Manoel Lobo estudou contabilidade na França, mas tinha predileção pelas letras ${ }^{11}$. Seu pai, o português Miguel da Fonseca Lobo, migrou para o rio Madeira em 1870, adquirindo uma enorme quantidade de terras para exploração da borracha junto à Província do Amazonas. Ali manteve relacionamento afetivo com uma índia Parintintin, que veio a se tornar a mãe de Manoel Lobo ${ }^{12}$. No início do século XX, Manoel Lobo retornou da Europa para assumir a empresa seringalista da família, pois seu pai havia se retirado para Fortaleza. Compreendendo que o conflito aberto com os Kagwahiva seria prejudicial aos interesses da economia extrativista naquele momento, Manoel Lobo desenvolveu uma estratégia mais branda para lidar com os indígenas. A partir de 1911, quando nomeado delegado de índios, passou a adotar os princípios e os regulamentos do SPI, como uma prática menos autoritária de atração dos indígenas. Sua estratégia foi evitar os embates e, ao mesmo tempo, deixar presentes em lugares específicos do rio Maicy.

O plano político e econômico de Manoel Lobo só teve início com a saída de Nimuendaju do Posto de pacificação. Nos relatos de viagem de outro servidor do SPI, Joaquim Gondim ${ }^{13}$, Manoel Lobo e Garcia de Freitas foram encarregados de mobilizar os Kagwahiva em diversas ocasiões, apresentando aos indígenas as novas tecnologias da sociedade envolvente. De fato, tal evento foi levado a cabo quando Garcia de Freitas planejou uma viagem pelas margens do rio Madeira com o objetivo de apresentar os "resultados da pacificação" aos comerciantes e aos outros seringalistas.

11 Segundo Leal (2013, p.201) no seringal Três Casas organizavam-se saraus literários com a participação de Péricles de Morais e Aníbal Teófilo. No Uruapiara também nasceu e trabalhou por muitos anos com Manoel de Souza Lobo o pai do historiador Raimundo Neves.

12 LEAL, Davi Avelino. Direitos e processos diferenciados de territorialização: os conflitos pelo uso dos recursos naturais no rio Madeira (1861-1932). Tese (Doutoramento em Sociedade e Cultura na Amazônia) Universidade Federal do Amazonas. 2013.

${ }^{13}$ GONDIM, Joaquim. A pacificação dos Parintintin: Koró de Uirapá. Manaus: edições do Governo do Estado, 1925, 2001. 
A aventura colonial de Garcia começou pelo Igarapé Traíra, juntamente com quatro indígenas Parintintin, a saber, "Diahy, Tukuhy, Igapuhê e Kanderê, que se tornaram célebres nos ataques ao posto de pacificação ${ }^{14}$. Antes da viagem, Garcia de Freitas, mediante suas relações com os seringalistas, criou um espaço fictício de amizade e bondade para a chegada dos indígenas nos Barracões. "No lugar São Sebastião, onde o gerente Manoel Barahuna os recebeu com carinho, oferecendo-lhes peixes e grandes quantidades de farinha e frutas ${ }^{15}$ ". Nesse cenário, um grande "cerco de paz ${ }^{16 "}$ e de exploração dos recursos naturais das terras indígenas começava a ser construído e articulado para envolver e atrair os diversos grupos indígenas do rio Madeira para os processos mercantis de troca.

No barracão São Domingos, a mesma encenação foi planejada pelos seringalistas. De barracão em barracão, visitaram todo o seringal Pádua, da família Sizino Monteiro. Ali, os Kagwahiva foram recebidos com festa e muitos presentes ofertados pelos seringalistas, de modo a que os indígenas os considerassem bons, pessoas com as quais valia a pena conviver.

Ora, a eficácia e a bondade do poder tutelar é também um reflexo de suas principais ambições. Nesse sentido, Souza Lima aponta que a retórica do SPI em prol da preservação dos grupos indígenas, o respeito pelas tradições míticas, os planos e as estratégias do Estado denotam:

O desenraizamento radical que permitiu criar populações e territórios brasileiros. Morte física por guerra aberta ou pacificação, necessária redução dos efetivos humanos a quebrar solidariedades e a facilitar outro tipo de morte, a alteridade ${ }^{17}$.

Em um plano imagético, a representação da bondade do seringalista não constitui propriamente uma novidade. É semelhante aos espelhos retorcidos da presença jesuítica na América. A nova representação é a imagem da disciplina, da domesticação do corpo e os efeitos de uma solidariedade simbólica.

O cenário preparado no seringal Três Casas para receber os indígenas contou com a presença de músicos, munidos de seus respectivos aparelhos sonoros, estranhos aos

\footnotetext{
${ }^{14}$ GONDIM, Joaquim. A pacificação dos Parintintin: Koró de Uirapá. Manaus: edições do Governo do Estado, p.52, 1925.

${ }^{15}$ GONDIM, Joaquim. A pacificação dos Parintintin: Koró de Uirapá. Manaus: edições do Governo do Estado, p.53, 1925.

${ }^{16}$ SOUZA LIMA, Antonio Carlos de. Um grande Cerco de Paz: poder tutelar, indianidade e formação do Estado no Brasil. Rio de Janeiro: Vozes, 1995.

${ }^{17}$ SOUZA LIMA, Antonio Carlos de. Um grande Cerco de Paz: poder tutelar, indianidade e formação do Estado no Brasil. Rio de Janeiro: Vozes, p.308, 1995.
} 
Kagwahiva, além de outras parafernálias desconhecidas. Tudo isso visava a produzir um efeito, a saber, o aguçamento da curiosidade indígena. Manoel Lobo, a um tempo instrumentalizado com os deveres atinentes ao seu cargo ocupado no SPI e com a sua ganância pessoal com respeito aos territórios indígenas, levou a cabo seu plano.

Em "Três Casas" os Parintintin detinham-se em apreciar o telefone que põe o escritório do Seringal em comunicação com a residência de Manoel Lobo. Perguntam insistentemente ao auxiliar Garcia quem tinha feito o aparelho e qual era a sua utilidade no seringal e, depois bem orientados, um deles o de nome Tukuhy, observou que também desejava possuir um telefone na sua maloca para falar com o pessoal do Posto, quando tivesse de pedir brindes ${ }^{18}$.

A imagem da empresa tutelar é tão profunda que talvez possamos racionalizá-la em termos de uma socialização primária ${ }^{19}$. As cenas em construção, elaboradas para receber os indígenas nos diversos pontos, nos levam a pensar nas recomendações postas no regimento do SPI. Segundo Souza $\operatorname{Lima}^{20}$, nas diretrizes do SPI constava que todos os trabalhos com os indígenas fossem relatados e fotografados, revelando um quadro permanente de vigilância e controle do corpo e da mente, uma disciplina que aproximava tutela e pedagogia.

As imagens descritas por Gondim revelam o papel de Manoel Lobo como mandatário de um poder tutelar. Os presentes, oferecidos na forma de brindes, camuflavam o real interesse de Manoel Lobo e de Garcia de Freitas. A imagem do "bom patrão", do "patrão acolhedor", do "defensor dos índios" coadunam com suas estratégias de pacificação. Segundo Leal, a imagem do "bom patrão" ${ }^{21}$ " fora construída a partir da ideia de "pai patrão". No entanto, o discurso do "bom patrão" esconde o desejo de mais

\footnotetext{
${ }^{18}$ GONDIM, Joaquim. A pacificação dos Parintintin: Koró de Uirapá. Manaus: edições do Governo do Estado, p. 54, 1925.

${ }^{19}$ Nesse caso especifico sobre a instauração da empresa tutelar no rio Madeira, teríamos que levar em conta o efeito socializador do Estado. Pierre Bourdieu percebe o efeito socializador da ação estatal como grande construtor da realidade social. Bernard Lahire (2015, p.1404) assinala que devemos caracterizar a socialização do Estado como um processo de fabricação social dos indivíduos levando uma multidão de realidades (escolares, politicas, jurídicas, administrativas). Ainda segundo Bourdieu (1993) e Lahire (2015), os processos de socialização ocorrem em diferentes momentos na vida de um indivíduo, o período da socialização primária essencialmente familiar distingue-se daquele dito secundário (escolas, instituições políticas, religiosas, culturais e esportivas). Essa distinção torna-se importante na medida em que ela faz lembrar que, nos primeiros momentos da socialização, a criança incorpora, na maior parte, dependência sociafetiva com relação ao contexto familiar que a cerca.

${ }^{20}$ SOUZA LIMA, Antônio Carlos de. Um grande Cerco de Paz: poder tutelar, indianidade e formação do Estado no Brasil. Rio de Janeiro: Vozes, p.308, 1995.

${ }^{21}$ LEAL, Davi Avelino. Direitos e processos diferenciados de territorialização: os conflitos pelo uso dos recursos naturais no rio Madeira (1861-1932). Tese (Doutoramento em Sociedade e Cultura na Amazônia) Universidade Federal do Amazonas, p, 203, 2013.
} 
produção. Podemos perceber que há no poder exercido uma força produtora que não pode ser reduzida nem à repressão nem à força física, mas que se sustenta a partir de mecanismos capilares que buscam produzir corpos dóceis, visando melhor eficácia no trabalho.

Bourdieu $^{22}$ ressalta que o poder não é apenas disciplinador dos corpos, mas, principalmente, algo que produz dominação simbólica. Não se reduz, portanto, à força repressora. No caso de Manoel Lobo, o poder simbólico é exercido mediante sua "bondade", que lhe conferiu uma autoridade carismática, comprovada na crença e no reconhecimento, por parte de seus fregueses, os Tupi- Kagwahiva e os seringueiros, de que ele era o "Papai Dobo"23".

O cenário do "bom patrão" produziu os efeitos pretendidos entre os aliados políticos de Manoel Lobo, principalmente entre a família Monteiro, assim também como junto ao SPI. Gondim, ao descrever o cenário da pacificação, mostrou-se conivente com as estratégias dos seringalistas.

O coronel Manoel Lobo obsequiou os índios com presentes. Outras cenas se passaram até o dia 15, quando o coronel Lobo tomou o vapor "Cidade de Teffé" com destino a "Pádua", levando em sua companhia o auxiliar Garcia e os heroicos Parintintin. A bordo, esses índios mostravam-se encantados com tudo o que viam e examinavam de perto. Subiram o toldo e puxaram a corda da sirena, descendo depois à sala das maquinas, onde se detiveram por mais de uma hora a apreciar o movimento de todo aquele mecanismo para eles complicado e desconhecido. Os excusionistas chegaram a Pádua no mesmo dia, rumando na manhã seguinte para suas malocas. O Coronel Lobo e o Sr. Ventura Freire, gerente do seringal, deram-lhe mais uma prova de carinho, acompanhando-os até o lugar conhecido por laguinho, onde os índios se despediram com gestos de visível emoção, demonstrando assim o seu reconhecimento pela boa hospitalidade que tiveram ${ }^{24}$.

Desde 1913, Manoel Lobo já vinha elaborando várias estratégias para retirar os Tupi-Kagwahiva de suas próprias terras. A pacificação mostrou-se a estratégia que surtiu o efeito esperado, pois, com a ajuda do SPI, Manoel Lobo conseguiu, finalmente, o domínio sobre as terras indígenas e os seus respectivos recursos naturais. A conquista e a estruturação do poder tutelar nos territórios Kagwahiva foi aos poucos espraiando-se. Não apenas os Parintintin, mas também outros grupos (Jiahui, Aparandê, Pain) foram aliciados com a ajuda dos servidores do SPI.

\footnotetext{
22 BOURDIEU, Pierre. Sobre o Estado. São Paulo: Cia das Letras, 2014.

${ }^{23}$ HUGO, Vitor. Desbravadores. Humaitá: Missão salesiana. (2 volumes), p.219, 1959.

${ }^{24}$ GONDIM, Joaquim. A pacificação dos Parintintin: Koró de Uirapá. Manaus: edições do Governo do Estado, p. 54-55, 1925.
} 
Diante disso, o que pensaram os nativos? Foram passivos ou tentaram pacificar o branco? Resistiram? Se considerarmos que os sistemas ameríndios de subjetivação também dialogam com o nosso sistema cosmológico, podemos imaginar que, nos limites de uma alteridade radical, os Tupi- Kagwahiva tentaram, igualmente, uma pacificação do branco (no caso, o Taipi in) no momento em que se pronunciaram, concordando em não mais fazer guerra, conforme informa Nimuendaju, "Acabou-se a nossa guerra contra vós ${ }^{25}$.

No entanto, isso não significou que as formas de resistência Kagwahiva tenham se anulado. A partir das relações políticas com os seringalistas e com o SPI, novas formas de resistência foram sendo gestadas. Os Aparandê e os Pain isolaram-se nas cabeceiras do rio Marmelos. Os Parintitin e os Jiahui ingressaram no modelo mercantil de trocas de produtos in natura por produtos industrializados.

A aproximação e o distanciamento foram percebidos de variadas formas pelos Kagwahiva. Nas representações de Gondim, um grupo doméstico dos Parintintin foi morar nas proximidades do barracão, abandonando sua Onga-Hu, rumando para o referido laguinho, antiga colocação de seringueiros.

O velho índio Cary, pai do guerreiro Aruká, passava a residir ali com oito pessoas de sua família, numa barraca adaptada, e muito embora se lembrasse ainda de acender a noite a sua coivara, pouco desejo nutria de voltar a maloca ${ }^{26}$.

Enquanto isso, outro grupo doméstico se estabeleceu nas imediações do posto indígena. Uma barraca foi construída pelos servidores do posto para abrigar os processos de atração. A sedentarização, enquanto primeira estratégia do SPI, começava a funcionar. Os grupos domésticos, que tinham como característica inerente a separação e o deslocamento por todo o território, agora passavam apenas a circular pelas roças e pelas áreas de coleta extrativa.

A sedentarização foi uma das estratégias dentro do modelo de pacificação do SPI.O efeito da pacificação envolveu estratégias, técnicas de intervenção espacial e temporal. Curt Nimuendaju, estabeleceu as bases metodológicas para o exercício de um processo de pacificação bem sucedido. Ao demonstrar tal modelo, fez inúmeras críticas às iniciativas missionárias e militares que tentaram elaborar expedições dentro das malocas indígenas.

\footnotetext{
${ }^{25}$ NIMUENDAJU, Curt. As tribos do Alto Madeira. Textos Indigenistas. São Paulo: Loyola, p. 124, 1982. ${ }^{26}$ GONDIM, Joaquim. A pacificação dos Parintintin: Koró de Uirapá. Manaus: edições do Governo do Estado, p. 55, 1925.
} 
É um conceito muito vulgar, mas completamente errado, ser o melhor meio de pacificar uma tribo hostil fazer uma expedição pacífica às suas malocas. Com tais entradas nunca se realizará a pacificação de uma tribo intratável, como a dos Parintintin. O pacificador tem de estabelecer-se permanentemente no território dela e obrigá-la com esta medida a entender-se pouco a pouco com ele, depois de ter se convencido da inexpulguibilidade da sua posição e das vantagens que a permanência dele trás para a sua tribo toda. A escolha de lugar para um posto de pacificação deve satisfazer a três condições seguintes: 1 - ser o posto estabelecido tão longe da zona povoada que se destaque dela a primeira vista e que a sua guarnição seja facilmente distinguida pelos índios dos outros moradores, geralmente seus inimigos. 2 - estar nas terras permanentemente habitadas pelos índios, mas não perto demais das suas malocas, para não causar o abandono delas, por medo de alguma surpresa. 3 - ficar ligado a zona do comercio por uma via de comunicação, a mais fácil possível e que seja transitável durante todo o $\mathrm{ano}^{27}$.

O modelo pacificador distribuído em fases e processos apoiava-se nas manobras espaciais. Nesse sentido, foi necessário construir um plano espacial, o posto indígena, para sua dominação e conquista. Uma guerra estava sendo travada em outro nível de ação. Cotejando com Souza Lima, o plano espacial de Nimuendaju desnuda as cenas de construção de um terceiro poder. "Um poder alienígena com potência para mediar, fazer relações e tutelar uma guerra que lhe preexistia ${ }^{28 "}$. Isto implica evidenciar uma força estrangeira com a capacidade de resistência a todo poderio bélico e tecnológico usado pelo Tupi- Kagwahiva quando atacavam um posto de pacificação. "Uma força que agia pela ameaça surda de transformar a resistência em um ataque, polarizando a vida daquele povo até ser insuportável não interagir" (idem).

Nimuendaju tinha clareza de suas estratégias teatrais, principalmente na manutenção de uma permuta desequilibrada entre o encontro de duas culturas. $\mathrm{O}$ plano espacial desenvolvido no posto indígena Nove de Janeiro se espraiou para os futuros postos no rio Maicy, rio Marmelos e rio Ipixuna. A estratégia, isto é, colocar em prática um jogo dos usos dos espaços, empregando uma quantidade de recursos advindos dos financiamentos controlados pelos seringalistas no rio Madeira, continuava.

Os presentes foram as armas simbólicas - o poder simbólico para construir a “paz”, numa tentativa prática de produzir o "grande cerco de paz”. O plano de poder de

\footnotetext{
${ }^{27}$ NIMUENDAJU, Curt. Os índios Parintintin do rio Madeira. Jounal de la Société des Americanistes de Paris. p. 59, 1924.

${ }^{28}$ SOUZA LIMA, Antônio Carlos de. Um grande Cerco de Paz: poder tutelar, indianidade e formação do Estado no Brasil. Rio de Janeiro: Vozes, p.170, 1995.
} 
Garcia de Freitas foi endossar os "brindes" nos diversos sentidos e significados, transformando uma relação de amizade e confiança numa relação cordial.

Efetivamente, a viagem realizada em conjunto com os indígenas, como um processo relacional para conhecer os seringais da família Monteiro e da família Lobo, tinha o objetivo de docilizar, por meio da relação "harmoniosa", a violência do embate, numa encenação de generosidade, de bondade e, ao mesmo tempo, de desprezo pela cultura do outro e pela presença indígena no rio Madeira.

Tukuhy, observou que também desejava possuir um telefone na sua maloca para falar com o pessoal do posto, quando tivesse de pedir brindes. O coronel Manoel Lobo obsequiou os índios com presentes e, quando observava, por intermédio do Sr. Garcia, de que ia mandar matar um boi para o almoço, um deles objetou: Na-ham! Daú Mimbab (Não! Não como xerimbambo ${ }^{29}$.

A relação "cordial” construída por Garcia e, sobretudo, por Manoel Lobo, nos permite visualizar que "a virtude deveria ser, na intenção do pacificador, demonstrar sua boa vontade quebrando as resistências à sua aceitação na qualidade de aliado superior, conduzindo ao abandono dos meios técnicos e costumes ${ }^{30 \%}$. Portanto, o cálculo estratégico do uso dos espaços como o posto indígena, o barracão e as aldeias tinham uma dimensão a ser alcançada, para produzir uma eficácia simbólica do poder emblemático instaurado naqueles espaços.

Consoante a isso, o fetiche dos presentes poderia provocar uma mudança social não somente no cotidiano da aldeia, mas nas relações entre os diversos grupos domésticos que apareciam nos postos indígenas. No limite da representação, os presentes, fincados nas cabeceiras de estacas, foram os melhores "signos e instrumentos de uma tecnologia muito superior à nativa no concernente ao poder de destruição e de resistência militar ${ }^{31}$ ".

No caso dos Tupi- Kagwahiva, quase todos os dias encontravam os referidos "brindes" simbólicos nos mais diversos lugares do território indígena. Com o afastamento de Nimuendaju em janeiro de 1923, a "política de presentes" foi alargada para outros rios.

Com a retirada do Sr. Curt, para Belém, entrara na chefia dos serviços de pacificação o seu auxiliar José Garcia de Freitas, que se houve com muita habilidade nessa delicada missão. Na manhã, do dia 21 de março (1923), embora desconhecido o caminho subiu o igarapé Nove de

\footnotetext{
${ }^{29}$ GONDIM, Joaquim. A pacificação dos Parintintin: Koró de Uirapá. Manaus: edições do Governo do Estado, p. 55, 1925.

${ }^{30}$ SOUZA LIMA, Antônio Carlos de. Um grande Cerco de Paz: poder tutelar, indianidade e formação do Estado no Brasil. Rio de Janeiro: Vozes, p.171, 1995.

${ }^{31}$ SOUZA LIMA, Antônio Carlos de. Um grande Cerco de Paz: poder tutelar, indianidade e formação do Estado no Brasil. Rio de Janeiro: Vozes, p.172, 1995.
} 
Janeiro em canoa, levando três trabalhadores, um índio de nome Horácio Mangury da tribo tupy, que servia no posto, como interprete, e vidro de remédio antiofídico. A viagem foi fatigante e morosa, tendo o pessoal atravessado sombrios igarapés e igapós solitários sem encontrar o menor rastilho dos Parintintins. Na incerteza da viagem, o pessoal regressou ao posto, deixando alguns brindes numa capoeira, que encontravam mais abaixo, a qual apresentava ainda vestígios de tapiris queimados e diversas árvores frutíferas ${ }^{32}$.

Os "brindes", como presentes simbólicos, foram acionados constantemente para construir uma relação de dependência conscientemente induzida a modos de ser alienígenas. Portanto, tal relação de dependência foi sustentada principalmente com recursos advindos dos seringalistas, tais como Manoel Lobo.

O "pai-patrão" (no caso, o Coronel Lobo), ao perceber a falta de recursos financeiros do Serviço de Proteção ao Índio, tratou de implementar a política do paternalismo. Tal ação vigorou até o início de 1926, principalmente com a presença da Missão Filadélfia ${ }^{33}$ entre os Tupi-Kagwahiva. Do ponto de vista estratégico, foi necessário projetar uma imagem magnânima que agradasse aos olhos estrangeiros. Assim, na "fase mais brilhante" da pacificação, "não mais se ouvia no zinco do barracão, o estalo de uma única flecha ${ }^{34}$ ".

A política paternalista vigorou até a saída da missão Filadélfia dos postos indígenas. No início de 1926, instaurou-se a política do clientelismo. Dali em diante o indígena precisaria trabalhar na coleta in natura para receber os "presentes". A relação mercantil passou a controlar a produção de roças, a coleta de castanhas e a força de trabalho indígena, principalmente dos Parintintin e dos Jiahui, no rio Maicy.

A cada recuo orçamentário do SPI, as iniciativas "pacificadoras" ficavam à mercê da disponibilidade econômica dos comerciantes seringalistas. No rio Madeira, os postos indígenas passaram a depender exclusivamente das alianças com os patrões e comerciantes, que passaram a explorar os recursos naturais e a força de trabalho indígena.

\footnotetext{
${ }^{32}$ GONDIM, Joaquim. A pacificação dos Parintintin: Koró de Uirapá. Manaus: edições do Governo do Estado, p. 49, 1925.

${ }^{33}$ A missão Filadélfia tinha objetivo realizar estudos e levantamentos sobre a fauna e a flora no rio Madeira. $\mathrm{E}$, também sobre as condições sociais em que se encontravam os povos indígenas do rio Madeira.

${ }^{34}$ GONDIM, Joaquim. A pacificação dos Parintintin: Koró de Uirapá. Manaus: edições do Governo do Estado, p. 55, 1925.
} 


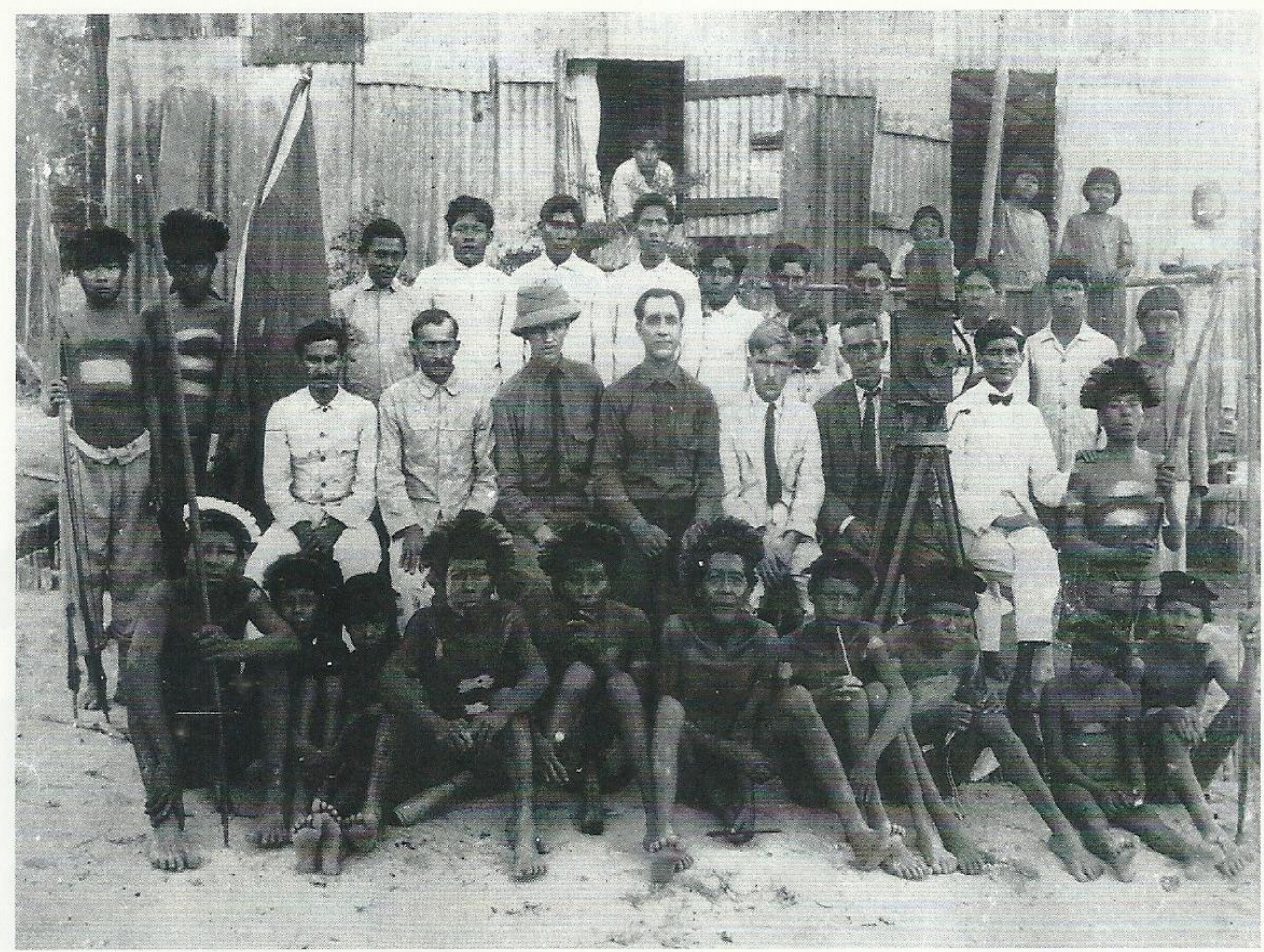

A expedição científica de Filadélfia (EUA) no posto de pacificação dos índios Parintintin (SPI - Relatório anual da IR1, 1924, p. 27, acervo do Museu do Índio). Negativo produzido por João Domingos Lamônica.

\section{A instalação do regime tutelar no rio Madeira: no tempo do "papai Dobo", delegados de índios, doenças e táticas de atração.}

A imagem do "cerco de paz" não poder ser compreendida meramente a partir da célebre frase de Rondon: "Morrer, se necessário for matar nunca". É preciso que atentemos às práticas simbólicas dos agentes e dos delegados de índios, que incorporaram táticas de atração, concentração e sedentarização às estruturas de poder do rio Madeira. Como em toda conquista, tais práticas surtiram o efeito esperado lançando mão da "técnica de divisão do povo invadido, desde as clivagens preexistentes e que podem ser instrumentalizadas, até as divergências passíveis de serem geradas pela ação do conquistador $^{35 \%}$.

As práticas de ação do SPI eram formas simbólicas, princípios de construção da realidade social. Os Agentes do SPI não eram apenas partículas movidas por forças físicas, eram agentes conhecedores que portavam estruturas cognitivas. Nesse sentido, o Poder tutelar, enquanto Estado, estava em condições de

impor de maneira universal, na escala de certa instância territorial, princípios de visão e de divisão, formas simbólicas, princípios de

\footnotetext{
${ }^{35}$ SOUZA LIMA, Antônio Carlos de. Um grande Cerco de Paz: poder tutelar, indianidade e formação do Estado no Brasil. Rio de Janeiro: Vozes, p.174, 1995.
} 
classificação, o que costumo chamar de nomos - lembrando a etimologia proposta por Benveniste segundo a qual nomos vem de nemo, "partilhar", "dividir", constituir partes separadas", por uma espécie de diachrisis, como diziam os gregos, de "divisão originária ${ }^{36}$.

Diante de tal fato, as técnicas de atração, postas em prática desde a presença de Nimuendaju, em 1921, no rio Madeira, serviram para mapear outros grupos Kagwahiva que tentavam se isolar em seus territórios da presença do branco. Serviram, também, para que o Estado realizasse um tipo de classificação arbitrária, ao parintinizar todos os grupos Kagwahiva e depois dividi-los em nomes genéricos tais como Tenharin, Parintintin e Jiahui, ignorando as autodenominações de cada povo.

A despeito disso, nem todos os estudiosos do tema consideraram que as práticas de instalação do regime tutelar no rio Madeira tenham transcorrido de modo absolutamente truculento. Nunes Pereira, em sua obra Moronguêtáa ${ }^{37}$, considerou que Souza Lobo, diante do drama Parintintin ante ao processo de pacificação, esboçou "uma compreensão profundamente humana, e não um interesse próprio em suas explorações de novas áreas de castanhais e seringais". Nunes Pereira ressalta que tal sentimento humanístico levou Souza Lobo a adotar uma posição diferente dos demais seringalistas em relação aos indígenas Parintintin. No entanto, as primeiras ações de Souza Lobo e Garcia de Freitas se deram no sentido de retirar os Kagwahiva das suas terras tradicionais e levá-los para os seringais Três Casas e Calama.

Os índios Parintintin, encaminhados posteriormente a Três Casas por Garcia e com os recursos que Manoel Lobo lhe concedeu generosamente, foram situando-se voluntariamente e com a anuência de Souza Lobo nas terras do seu seringal de Três Casas ${ }^{38}$.

Se em um primeiro momento Souza Lobo representou os interesses do SPI, como delegado de índios, em um segundo momento transmutou-se no seringalista, preocupado com os seus próprios interesses. É nesta singularidade que podemos compreender a dupla representação de Souza Lobo, o "patrão" e o "delegado de índios", ao, por assim dizer, anular a si mesmo em nome de seus agregados, indígenas e trabalhadores, recorrendo constantemente à abnegação impessoal. No entanto, não há nada mais profundo e destrutivo do que a estratégia da abnegação impessoal. $\mathrm{O}$ efeito da abnegação impessoal

\footnotetext{
${ }^{36}$ BOURDIEU, Pierre. Sobre o Estado. São Paulo: Cia das Letras, p.214, 2014.

${ }^{37}$ NUNES PEREIRA, Manoel. Moronguêtá: um decameron indígena (v 2). Rio de Janeiro: Ed. Civilização Brasileira, p.542, 1985.

${ }^{38}$ NUNES PEREIRA, Manoel. Moronguêtá: um decameron indígena (v 2). Rio de Janeiro: Ed. Civilização Brasileira, p.544, 1985.
} 
permite aos mandatários Souza Lobo e Garcia de Freitas tornarem-se donos da verdade. Os mandatários apropriam-se dos valores universais, requisitam a moral e açambarcam as noções de povo, liberdade, tornam-se, conforme Bourdieu, "a medida de todas as coisas, passando a falar em nome do grupo e tornando-se necessário para a sobrevivência do coletivo ${ }^{39}$ ".

Souza Lobo e Garcia de Freitas produzem o que Bourdieu classifica como o "efeito de oráculo" (idem), isto é, uma autêntica duplicação da personalidade, da representatividade, frente aos seus interesses pessoais e frente ao poder tutelar. São, ao mesmo tempo, divergentes e convergentes aos anseios depositados pelos Kagwahiva quando foram morar no Seringal Três Casas e Calama.

Logo após os primeiros dois anos de contato, os servidores do SPI, através de informações colhidas entre os Parintintin, relataram o surgimento de outros grupos indígenas na mesma região. No início de 1925, Garcia de Freitas organizou várias expedições em busca dos "clãs guerreiros". Nos relatórios do SPI de 1925 consta que, num primeiro momento, alguns grupos como os "Odiarhúebe", estavam localizados às margens do rio Branco. Em outro relatório, de 1926, o mesmo grupo indígena foi apontado como habitantes da região do igarapé Amazônia, afluente do rio Marmelos. Pode-se perceber através destas informações que os Kagwahiva estavam em constante movimento, não apenas fazendo guerra, mas também produzindo diversas trocas intertribais. Nesse sentido, o SPI, ao compreender a dinâmica Kagwahiva na bacia do rio Madeira, passou a repensar suas estratégias de atração para o "cerco de paz".

O posto do Rio Branco, afluente do Marmalos, tomará a seu cargo a pacificação da tribu selvagem Odiarhúebe, que quer dizer gritadoresflechadores. Esses índios, que vivem em plena floresta, habituados a sua vida nomada, acabam de aparecer em vários seringais do alto Rio Branco e de seus afluentes, queimando tapirys, que encontraram nos lugares por eles visitados em outros tempos, quando tiveram de sustentar luctas com a famosa tribo Parintitin, ora em plenas relações (sic) com o pessoal do posto de pacificação no rio Maicy-Mirim ${ }^{40}$.

Segundo Peggion ${ }^{41}$, quanto às relações entre os Parintintin e os Jiahui, as informações colhidas sempre partiam da perspectiva dos primeiros, uma vez que os segundos se mantinham avessos ao contato. Isso pode ser percebido no relatório de Bento

\footnotetext{
${ }^{39}$ BOURDIEU Pierre. Coisas Ditas. São Paulo: Brasiliense, p. 196, 2004.

${ }^{40}$ LEMOS, Bento Martins Pereira de. Relatório encaminhado ao Diretor do SPI, Sr. Dr. José Bezerra Cavalcante. Referente aos serviços da IR1 nos exercícios de 1925, p.20. Rio de Janeiro, Museu do Índio. 41 PEGGION, Edmundo. Relatório de identificação e delimitação da Terra Indígena Jiahui no município de Humaitá-AM. Fundação Nacional do Índio /FUNAI, 1999/2000.
} 
de Lemos, de 1925, no qual os Parintintin definem suas perspectivas em relação aos Jiahui.

Segundo informações colhidas entre os Parintintin, pelo encarregado do Posto do Maicy-Mirim, os Odiarhúebe falam o mesmo dialeto e se adoptam quase os mesmos costumes daquella tribu, havendo todavia, entre ambas, um requinte de hostilidade oriundo de sua índole guerreira, que os tornam inimigos rancorosos. Ao contrário dos Parintintin que costumam cortar os cabellos em torno da cabeça, os Odiarhúebe conservam-nos vastos e compridos; mas a exemplo daqueles também trazem o pênis envolvido por um tubo de folhas de arumã, em forma cilíndrica. As suas akanitaras são feitas de penas de japu e de araras e as flechas apresentam o mesmo feitio e os mesmos adornos que se observam nas armas guerreiras dos Parintintin ${ }^{42}$.

A intenção de pacificar os outros grupos Kagwahiva foi explicitada em vários relatórios enviados para a inspetoria do SPI no Amazonas. Os conflitos surgiam em diversas áreas do território do rio Madeira. Nesse período, o SPI readmitiu Garcia de Freitas para o serviço de pacificação dos outros grupos indígenas que estavam aparecendo.

Uma das estratégias do SPI foi pôr em prática a instalação de outros postos indígenas em rios específicos para funcionarem como dispositivos de controle sobre os recursos naturais para os indígenas e para os regionais. Entre os anos de 1921-1928 foram instalados seis postos indígenas, entre os rios Ipixuna, Marmelos e Maicy.

\begin{tabular}{|c|c|c|c|c|}
\hline \multicolumn{5}{|c|}{ QUADRO DE POSTOS INDÍGENAS NA BACIA DO RIO MADEIRA } \\
\hline $\begin{array}{c}\text { POSTO INDÍGENA } \\
\text { EMARANEL }\end{array}$ & $\begin{array}{c}\text { Médio Rio } \\
\text { Maicy }\end{array}$ & Manicoré & $1920-1931$ & $\begin{array}{c}\text { Parintintin } \\
\text { Pirahã }\end{array}$ \\
\hline ANTONIO PAULO & Baixo Maicy & Manicoré & $1924-1931$ & $\begin{array}{c}\text { Parintintin } \\
\text { Pirahã } \\
\text { Torá }\end{array}$ \\
\hline $\begin{array}{c}\text { CAPITÃO } \\
\text { PORTÁTIL }\end{array}$ & Maicy-Mirim & Manicoré & $1921-1931$ & Parintintin \\
\hline RIO IPIXUNA & $\begin{array}{c}\text { Médio Rio } \\
\text { Ipixuna }\end{array}$ & Manicoré & $1926-1931$ & $\begin{array}{c}\text { Parintintin } \\
\text { Odiarhúebe }\end{array}$ \\
\hline $\begin{array}{c}\text { ALTO RIO } \\
\text { IPIXUNA }\end{array}$ & $\begin{array}{c}\text { Alto Rio } \\
\text { Ipixuna }\end{array}$ & \multirow{2}{*}{ Manicoré } & $1926-1931$ & Parintitin \\
\hline CANAVIAL & $\begin{array}{c}\text { Boca do Rio } \\
\text { Ipixuna }\end{array}$ & & & \\
\hline
\end{tabular}

Tabela 01: Fonte Relatório da Inspetoria do SPI no Amazonas de 1927.

\footnotetext{
${ }^{42}$ LEMOS, Bento Martins Pereira de. Relatório encaminhado ao Diretor do SPI, Sr. Dr. José Bezerra
} Cavalcante. Referente aos serviços da IR1 nos exercícios de 1925, p.20 Rio de Janeiro, Museu do Índio. 
Os postos Indígenas no rio Madeira serviram como os olhos de controle do Poder tutelar. O Posto, enquanto metáfora do panótpico de Jeremy Bentham ${ }^{43}$, é o olho que tudo vê, observa, descreve, informa, reprime e controla as ações dos corpos que antes movimentavam-se por todo o território tradicional. Um controle da mente, da língua falada, do território de uso. Um poder vigilante e disciplinador que se iniciava todas as manhãs com o aprendizado do Hino Nacional.

Nesta lógica disciplinadora, o SPI acionava o poder através de três planos espaciais estratégicos: Diretoria Geral, Inspetorias Regionais e, por último, os postos Indígenas de Pacificação e Vigilância. O modelo de ação seguia as diretrizes da Diretoria Geral, responsável pela elaboração das ações práticas contidas nos regimentos de 1910 e 1911. Segundo Souza Lima, no âmbito regional os recursos financeiros e políticos disponíveis permitiam a viabilidade de acesso aos diversos interiores do Brasil, principalmente da Amazônia, pois:

Os interesses econômicos em explorar terras ocupadas por nativos e com as provas de invasão estrangeira do território nacional, dentre outros fatores, instalavam-se as unidades responsáveis pela ação direta do Serviço junto às populações indígenas e aos trabalhadores nacionais ${ }^{44}$.

Na prática, os postos indígenas foram unidades de ação, de concentração e atração. Abarcavam povos indígenas linguística e cosmologicamente diferenciados, inimigos históricos juntos em um mesmo lugar, apenas para atender aos interesses dos grupos dominantes no rio Madeira e por toda Amazônia. Por outro lado, o caráter transitório dessas unidades de ação revelava o destino e o tipo de instrumento a ser criado no local, ou seja, dependendo do nível de ação e estratégia, criava-se um posto, um povoado ou um centro agrícola indígenas.

Notemos que, diferente das outras unidades de ação, o posto indígena representou duas imagens emblemáticas. A primeira, uma estrutura militar e, a segunda, uma estrutura administrativa com cargos de chefia e subordinados, como podemos perceber nos relatos de Nimuendaju.

Despachei a maior parte do pessoal, ficando somente com o ajudante Amaro e mais cinco homens, caboclos amazonenses da beira do Madeira. O posto consiste num limpo na margem do rio, cercado com arame farpado, com uma porteira permanentemente aberta. A casa, toda

\footnotetext{
${ }^{43}$ BENTHAM, Jeremy. O panótpico. Belo Horizonte: Autentica Editora, 2019.

${ }^{44}$ SOUZA LIMA, Antônio Carlos de. Um grande Cerco de Paz: poder tutelar, indianidade e formação do Estado no Brasil. Rio de Janeiro: Vozes, p.230, 1995.
} 
feita de chapas de ferro de zinco, se ergue perto do barranco e contém três quartos, a cozinha e a varanda que cerca a casa por detrás e por um dos lados. Todas as portas dão para essa varanda. A frente virada para o mato está construída de uma forma que entre o telhado saliente e a beira superior da parede fica um vão de $80 \mathrm{~cm}$ de largura, de maneira que, em caso de um ataque, as flechas só podem alcançar o telhado ou a parede já abaixo do vão, pelo qual se pode observar comodamente os assaltantes e também ser visto por eles quando se lhes queria fazer alguma demonstração ${ }^{45}$.

O posto indígena Nove de Janeiro foi estruturado como um bunker. Tal proposta refletia as estratégias militares de guerras e conquistas, elaborada pelo SPI em diversas áreas conflituosas que envolviam povos indígenas e as frentes de expansão econômica na Amazônia no início do século XX. Consoante a isto, o posto, enquanto representação militar, revelava uma modalidade de poder de um Estado que se imaginava nacional, ou,

de uma comunidade política dotada de um exército profissional, comunidade esta entendida aqui como um conjunto de redes sociais estatizadas, com pretensões a abarcar e submeter a multiplicidade de comunidades étnicas diferenciadas ${ }^{46}$.

A outra imagem possível, isto é, uma "porteira permanentemente aberta", foi a condição básica para o modelo de atração e sedentarização proposto, pois, diante de povos com características inerentes ao território, ora de movimento, ora de separação, sedentarizar mostrou-se a única alternativa, "vencendo-lhes a partir de ações sobre suas ações e o uso da não violência - sua resistência em se fixarem em lugares definidos pela administração" (idem).

Garcia de Freitas, em suas ações administrativas, seguiu as estratégias pensadas pelo SPI, no tocante à edificação dos seis postos indígenas nos afluentes do rio Madeira, erguidos durante sua coordenação. No relatório de 1930, enviado para Bento de Lemos, o servidor descreve os novos processos de atração que passaram a ocorrer naquele período, relato este recriado pelo próprio Bento de Lemos.

Este ano intensifiquei o trabalho de aproximação entre várias hordas, começando pelos silvícolas estabelecidos entre os rios Machado e Marmelos, Maicy e afluentes, notadamente o Amazonas.

Conforme vossa determinação estacionei o tempo no posto indígena Capitão Portátil que ficou sendo nosso ponto de base para reconhecimento e estudos para a aproximação e pacificação dos índios "Odiahub", após ter fabricado regular quantidade de farinha, levei uma parte e deixei a outra, assim como a maior parte de gêneros e

\footnotetext{
45 NIMUENDAJU, Curt. Os índios Parintintin do rio Madeira. Jounal de la Société des Americanistes de Paris. p. 62, 1924.

46 SOUZA LIMA, Antônio Carlos de. Um grande Cerco de Paz: poder tutelar, indianidade e formação do Estado no Brasil. Rio de Janeiro: Vozes, p.74, 1995.
} 
mercadorias entregues ao encarregado daquele posto, a quem autorizei a retirar o que precisasse visto o serviço do posto se prender ao mesmo ideal ${ }^{47}$.

No ano de 1930, o SPI intensificou suas estratégias de atração não somente em relação ao Povo Jiahui, mas também com respeito a todos os povos que circulavam nas calhas e afluentes da bacia do rio Madeira. É interessante mencionar que os Parintintin eram os mediadores por excelência das relações entre os postos e os grupos que ainda não haviam sido pacificados. O processo de exploração da força de trabalho era efetivado nas grandes plantações de roça. A farinha veio a ser um dos elos fundamentais nas relações de contato com outros grupos Tupi-Kagwahiva. As mercadorias industrializadas complementaram o fetichismo mágico do contato. $\mathrm{O}$ encanto com o novo, o desconhecido, transformou os Kagwahiva em reféns dos brindes do colonizador.

A cobiça de Garcia de Freitas pelas riquezas oriundas das terras indígenas transcende o ideal rondoniano. De fato, extrapola o "cerco de paz" estabelecido pelo regimento do SPI. Desde a criação do SPI, em 1910, os Tupi-Kagwahiva já constavam na classificação arbitrária. Apareciam numa lista referida a povos que deveriam ser pacificados e eram classificados nos Relatórios de Província como “indomáveis antropofágicos" e aguerridos, desde o final do século XVIII. Pode-se imaginar que as únicas alternativas possíveis estariam atreladas aos modelos de guerra e conquista. No entanto, o modelo utilizado foi aquele que estabelecia uma guerra sem o uso das armas, uma guerra silenciosa, ancorada na permanência no território alheio com o intuito de criar relações de dependência e confiança.

Assinala Edmundo Peggion ${ }^{48}$ que inúmeras intenções conduziram à pacificação dos Tupi-Kagwahiva. Porém, no início do século XX, os conflitos entre seringalistas e indígenas só aumentavam nos afluentes do rio Madeira. A casa Monteiro, dona do seringal Paraíso, financiou algumas expedições comandadas pelo encarregado do seringal, Caetano Centauro. Comenta Victor Hugo ${ }^{49}$ que "Caetano Centauro, ao parar em um dos afluentes do rio Maicy, deu o nome do dia de sua chegada, 09 de Janeiro".

Hoje o igarapé Nove de Janeiro é parte da terra indígena Parintintin, que foi demarcada em 1998. Foi neste extenso igarapé, que atravessa a Transamazônica, que

\footnotetext{
${ }^{47}$ FREITAS, José Garcia de. Relatório encaminhado ao inspector Bento Pereira de Lemos referente ás atividades da IR1 nos exercícios de 1929-1930. (Filme 33, planiha 396, pp02-12), Rio de Janeiro, Museu do Indio, p. 02, 1930.

48 PEGGION, Edmundo. Relatório de identificação e delimitação da Terra Indígena Jiahui no município de Humaitá-AM. Fundação Nacional do Índio /FUNAI, 1999/2000.

${ }^{49}$ HUGO, Vitor. Desbravadores. Humaitá: Missão salesiana. (2 volumes), p.219, 1959.
} 
surgiram os primeiros contatos de pacificação entre Nimuendaju e os Kagwahiva. A partir de 1920, o inspetor Bento de Lemos viajou por todo o rio Madeira para elaborar um plano de gastos econômicos para a implementação da pacificação. Sua avaliação econômica sustentou que, para tanto, seriam necessários 90 mil contos de réis, além da participação ativa do etnólogo Curt Nimuendaju.

Entre os anos de 1921 e 1923, Nimuendaju viveu seis meses entre os Kagwahiva, no Posto Nove de Janeiro. O trabalho do etnólogo foi interrompido pela falta de verbas orçamentárias e, talvez, devido à maneira como Nimuendaju procedia entre os Parintintin $^{50}$, mal vista pelos seringalistas que também patrocinavam o projeto pacificador.

Com o afastamento de Nimuendaju da frente pacificadora, o posto indígena Nove de Janeiro passou a ser administrado por Garcia de Freitas. A partir desse período iniciouse o processo que daria corpo à submissão dos indígenas diante da população regional. À proliferação de epidemias de sarampo, gripe e coqueluche, acumulou-se a descaracterização da língua e o fator demográfico negativo.

A partir de 1925, alguns grupos Parintintin já estavam aldeados nas proximidades do posto indígena. Outros grupos ainda continuavam fazendo guerra entre si. De acordo com o relatório do SPI de 1925, no posto continuaram a residir com suas famílias, "os índios Cary, Moaguy, Maracuty e Canderê, integrando-se de preferência ao serviço de caça e de pesca". Os trabalhadores costumavam "visitar as malocas nos casos de necessidade, dando remédios aos silvícolas que combalidos no seu estado físico, não

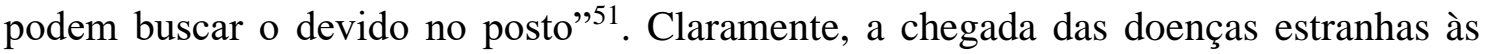
aldeias deveu-se aos contatos com os regionais.

Nunes Pereira, servidor do SPI, visitou as aldeias dos Parintintin em 1925, a convite de Manoel Lobo, e pode presenciar como estes indígenas foram retirados de suas terras tradicionais e encaminhados por Garcia de Freitas aos seringais Três Casas e Calama. Conforme Pereira,

Durante esse movimento, o 'catarro' que tanto temiam, a pneumonia e o paludismo foram fazendo entre aquela gente cujos os hábitos e resistência física natural, dados aos seus caracteres somáticos, exaltados

\footnotetext{
${ }^{50}$ Talvez podemos afirmar que Nimuendaju construiu uma relação simétrica com os Parintintin Kagwahiva, diferente de Garcia de Freitas e Manoel Lobo que explorava a mão de obra indígena nos trabalhos de roça e coleta da castanha numa relação assimétrica.

${ }^{51}$ LEMOS, Bento Martins Pereira de. Relatório encaminhado ao Diretor do SPI, Sr. Dr. José Bezerra Cavalcante. Referente aos serviços da IR1 nos exercícios de 1925, p.23-24. Rio de Janeiro, Museu do Índio.
} 
por Nimuendaju, sofreram um impacto que não se previra e todos os traumas e consequências ${ }^{52}$.

Nunes Pereira, influenciado pelo pensamento positivista, percebia o processo de contato e pacificação como um acaso do papel destrutivo das frentes de expansão econômica no rio Madeira no início do século XX. Nesse período, temos o desaparecimento quase total da figura dos Ipaji ${ }^{53}$ entre os Tupi-Kagwahiva. Os Ipajís foram as maiores vítimas das epidemias trazidas pelo efeito da pacificação, dado que as doenças derrubaram principalmente idosos e crianças. Talvez, a partir de 1930 entre os Parintintin já não existisse nenhum Ipají. A tradição do xamanismo, aos poucos, deixou de ser repassada. Talvez, também, devido às suas práticas de cura não terem logrado êxito, os Ipajís tenham perdido sua importância. De um jeito ou de outro, as doenças, as guerras, os conflitos nos afluentes do rio Madeira foram as principais causas para a perda da tradição xamânica entre os Tupi-Kagwahiva. Os Parintintin informam a presença dos Ipají entre os Jiahui como detentores de um grande poder xamânico.

Os Parintintin tomados pela sua superstição natural que assalta o espírito de quase todas as tribos tem um imenso pavor fetichista daqueles seus parentes e inimigos. Dizem eles que, acirrados pela vingança, os Odiarhuebe costumam enviar-lhes à noite grandes morcegos que lhes roubam os cabelos, aplicando-os nos processos de bruxaria que de vez em quando, transmitem os piores males às suas malocas ${ }^{54}$.

Nos anos de 1930, os Parintintin e os Jiahui foram incorporados definitivamente ao modelo seringalista de exploração econômica. Possivelmente, os Ipají Jiahui desapareceram do contexto Kagwahiva nas décadas seguintes e, com isso, todo conhecimento xamânico dos Tupi-Kagwahiva. Neste ínterim, a ação de Garcia de Freitas foi atrair os Apairandê e os Pain e forçá-los ao trabalho de coleta de produtos in natura, tais como o óleo de copaíba, sorva e a castanha. Vale ressaltar que, com o aumento do valor do hectolitro ${ }^{55}$ da castanha ultrapassando o montante de 120 mil réis no mercado internacional e com a decadência da borracha, a castanha brasileira tornou-se o produto

\footnotetext{
${ }^{52}$ NUNES PEREIRA, Manoel. Moronguêtá: um decameron indígena (v 2). Rio de Janeiro: Ed. Civilização Brasileira, p.544, 1985.

${ }^{53}$ Waud Kracke define que o Ipají ou Xamã era o ser carregado de poder e de cântico. O Ipají era também uma atribuição a algo ou a alguém, um ser que detinha o poder xamânico e um status, senão um tipo de atuação dentro do seu grupo (KRACKE 1967, p.05).

${ }^{54}$ LEMOS, Bento Martins Pereira de. Relatório encaminhado ao Diretor do SPI, Sr. Dr. José Bezerra Cavalcante. Referente aos serviços da IR1 nos exercícios de 1925, p.20-22. Rio de Janeiro, Museu do Índio.

$55 \mathrm{O}$ hectolitro era um sistema de medida para venda da castanha no Pará. Cada hectolitro equivalia a cem litros de castanha.
} 
extrativista com maior rentabilidade econômica em toda a Amazônia, a partir dos anos de $1930^{56}$

Os grupos domésticos Parintintin conviviam nos arredores do seringal Três Casas, onde trabalhavam para Manoel Lobo na coleta da castanha, na abertura de roças, ou como guia canoeiro. Outra característica emblemática desse período é o número de regionais e grupos indígenas estabelecidos no mesmo posto indígena. Consta nos relatórios do SPI de 1930 que no posto indígena Antônio Paulo Amarantes se encontravam grupos domésticos Parintintin, Pirahã, Torá e regionais, responsáveis pela produção e organização econômica das roças e da coleta de castanha ${ }^{57}$.

Cotejando com Peggion, a possibilidade de uma convivência "pacífica" entre brancos e povos indígenas corresponderia ao ideal positivista de tornar o imenso território amazônico em uma região de progresso ${ }^{58}$. Tal interesse congregava esforços conjuntos que objetivavam transformar os povos indígenas em grupos étnicos em diferentes territórios, demarcando-os como reservas ou como futuras vilas indígenas.

Mas, a verdade é que devemos encaminhar o serviço de modo que feita a pacificação de todas as malocas Parintintin, fraternizados todos os Tuchauas, possamos fundar na região a villa Cauahib, nação brasileira e cercando-a de merecido com um patrono agrícola-profissional para os rapazes, uma escola profissional para as moças e outros melhoramentos compatíveis com os nossos intentos civilizadores ${ }^{59}$.

Com efeito, estava em jogo a possibilidade de transformar diversas nações, espalhadas em um vasto território chamado Brasil, em uma única "nação", em uma "comunidade imaginada", dotada de uma língua oficial, um único hino, um único território como um Estado-Nação ${ }^{60}$. Tal perspectiva se reforçou quanto à conjectura acerca da presença/ausência dos poderes de Estado entre os diversos povos "nativos". Nesse caso, poderíamos refletir sobre "a montagem de quadros e mapas capazes de

\footnotetext{
${ }^{56}$ LARAIA, Roque de Barros; MATTA, Roberto da. Índios e Castanheiros: a empresa extrativista e os índios no médio Tocantins. Rio de Janeiro: Paz e Terra, 1978.

${ }^{57}$ MELO, Joaquim. A política indigenista no Amazonas. Manaus: edições do Governo do Estado, 2009.

${ }^{58}$ PEGGION, Edmundo. Brancos e Índios no Rio Madeira: 1850-1950. Contato e Identidade Étnica. Monografia de Bacharelado em Ciências Sociais. Universidade Estadual Paulista/Campus Araraquara. São Paulo, 1992.

${ }^{59}$ LEMOS, Bento Martins Pereira de. Relatório do Inspetor referente aos trabalhos realizados nos exercícios de 1930 e 1931, na Inspetoria do Amazonas e Acre. Acervo do SPI/Museu do Índio, p.21-22, 1931.

${ }^{60}$ ANDERSON, Benedict. Comunidades Imaginadas: reflexões sobre a origem e a expansão do nacionalismo. Lisboa: Edições 70, 2005.
} 
produzir retratos" da ação estatal no espaço ao longo do tempo, dando elementos morfológicos sobre a formação simbólica e social do Estado ${ }^{61}$.

Ora, o poder tutelar agiu integrando diversos elementos simbólicos, como a imposição da vestimenta, a substituição dos cânticos ritualísticos pelo Gramofone como elemento mágico capaz de transmitir o Hino Nacional, substituindo as flautas Irerua; a presença do sistema escolar; os modos à mesa. Um processo civilizador como parte integrante de uma "nova nação".

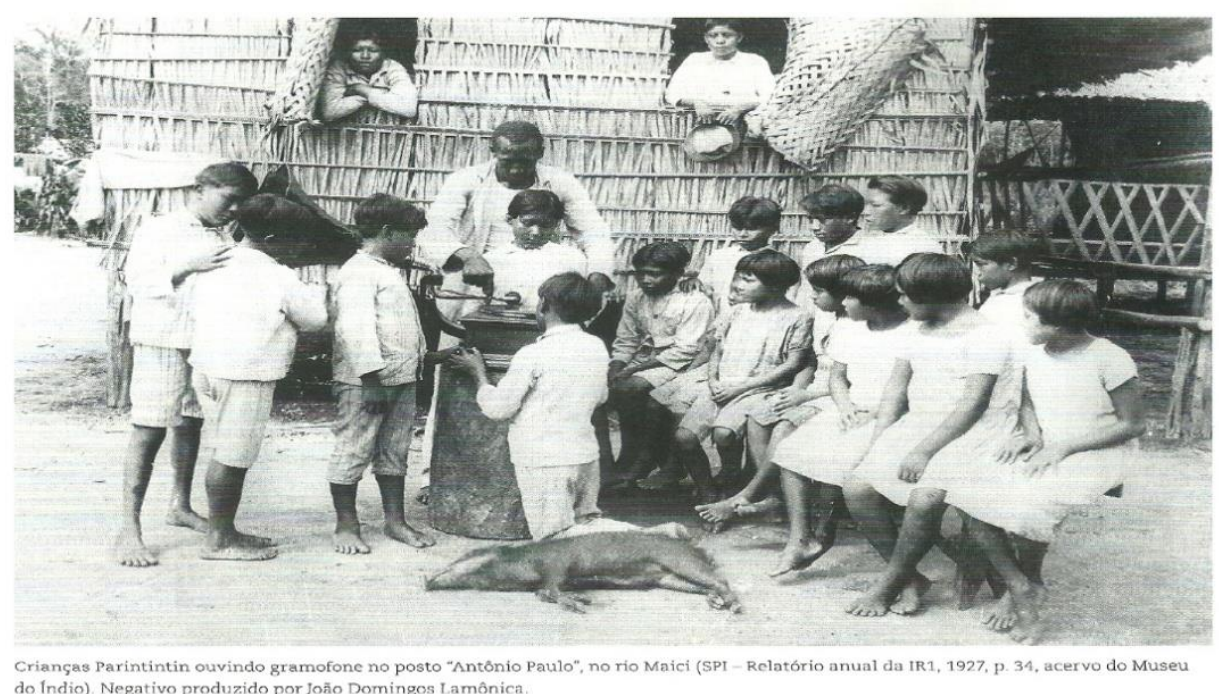

O plano estratégico de Bento de Lemos, ao pensar sobre a futura vila Cauahib, se coadunava com as ações dos encarregados dos postos indígenas. Naquele período, os anos 1930, alguns postos já estavam convivendo com grupos étnicos culturalmente diferenciados e inimigos históricos. Nesse emaranhado de impingimento simbólico e físico, mais uma vez surgiu a figura de Garcia de Freitas, readmitido pelo SPI e recomendado pela Missão Salesiana como um homem de extrema habilidade no comando das "pacificações ${ }^{62 "}$ "

O objetivo de Garcia de Freitas era reestruturar novas missões para pacificar os chamados "grupos desavindos" que ainda guerreavam entre si e se insurgiam contra a permanência de regionais em suas terras. No entanto, quando analisamos os relatórios de 1930 do SPI, verificamos que parte do território tradicional tinha sido ocupado pelos comerciantes e seringalistas para a comercialização de castanha. O território do Povo

\footnotetext{
${ }^{61}$ SOUZA LIMA, Antônio Carlos de. Um grande Cerco de Paz: poder tutelar, indianidade e formação do Estado no Brasil. Rio de Janeiro: Vozes, p.240, 1995.

62 PEGGION, Edmundo. Brancos e Índios no Rio Madeira: 1850-1950. Contato e Identidade Étnica. Monografia de Bacharelado em Ciências Sociais. Universidade Estadual Paulista/Campus Araraquara. São Paulo, 1992.
} 
Pirahã havia sido vendido, por Garcia de Freitas, para o comerciante José Alecrim, que no período da castanha explorava a força de trabalho indígena.

Consta ainda que os castanhais foram esbulhados pelos seringalistas que se auto intitulavam “protetores dos índios”. Segundo Peggion, nesse período o castanhal QuanduOga se chamava Boa Esperança e estava sob a posse de Manoel Lobo. O posto Indígena Antônio Paulo, passou a pertencer à família Monteiro (fundadora de Humaitá), que lhe deu o nome Paraíso ${ }^{63}$. É oportuno frisar que nesta área existia um imenso castanhal.

$\mathrm{Na}$ busca incessante por outros grupos Kagwahiva, Freitas se deparou com um pequeno grupo dissidente dos Jiahui, os Pain. Em seu relatório ${ }^{64}$, relata que prendeu uma mulher e seus dois filhos, com a intenção de fazê-los mensageiros para um acordo de Paz. Ao entrarem em contato com os Pain, os encarregados de Garcia voltaram ao posto para buscar mantimentos e presentes para agradar aos índios. Mas no retorno não encontraram ninguém, apenas vestígios e estilhaços de guerra entre os Pain e possivelmente outro grupo Kagwahiva. Com o passar dos anos, os Jiahui foram localizados no igarapé Amazônia, possivelmente o mesmo grupo doméstico Pain ${ }^{65}$.

A aventura do contato colonial Kagwahiva não ficou restrita somente aos seringais do rio Madeira, pois a relação estreita estabelecida entre os agentes do SPI e os seringalistas do rio Madeira possibilitou a conjugação de interesses. Segundo Bento de Lemos, numa viagem oficial alguns Parintintin foram "em companhia do Coronel Manoel de Souza Lobo desta inspetoria em Três Casas no Madeira que os trouxe daquela região ${ }^{66 "}$. Nesta ocasião, várias crianças e adolescentes foram levadas pelo SPI para trabalhar nas oficinas de alfaiataria. Outras foram encaminhadas para a escola de ferreiros, em Manaus.

Segundo Rocha Freire ${ }^{67}$, as imagens de crianças aprendendo um ofício funcionavam como um instrumento de marketing pessoal e institucional do SPI,

\footnotetext{
63 PEGGION, Edmundo. Brancos e Índios no Rio Madeira: 1850-1950. Contato e Identidade Étnica. Monografia de Bacharelado em Ciências Sociais. Universidade Estadual Paulista/Campus Araraquara. São Paulo, 1992.

${ }^{64}$ FREITAS, José Garcia de. Relatório encaminhado ao inspector Bento Pereira de Lemos referente ás atividades da IR1 no exercício de 1930. Rio de Janeiro: Museu do Indio, 1930.

65 PEGGION, EDMUNDO. Relatório de identificação e delimitação da Terra Indígena Jiahui no município de Humaitá-AM. Fundação Nacional do Índio /FUNAI, 1999/2000.

${ }^{66}$ LEMOS, Bento Martins Pereira de. Relatório encaminhado ao Diretor do SPI, Sr. Dr. José Bezerra Cavalcante. Referente aos serviços da IR1 nos exercícios de 1925, p.02-05. Rio de Janeiro, Museu do Índio.

${ }^{67}$ FREIRE, Carlos A. da Rocha. O SPI na Amazônia: política indigenista e conflitos regionais (19101932). Rio de Janeiro: Museu do Índio, 2009.
} 
possibilitando a conquista de legitimidade política. A imprensa constituía-se na principal instância de produção cultural da sociedade colonizadora à época.

As imagens denunciavam o efeito simbólico da representação do poder estruturado num sistema formal de aprendizagem, ou seja, era preciso tornar o, por assim dizer, "nativo", em um alfaiate ou em um ferreiro. Desta forma, o plano civilizador do SPI foi, ao mesmo tempo, desencarnar o nativo de suas estruturas cosmológicas e criar um "nativo civilizado", com uma profissão identitária. Um nativo que saberia lidar com os modos à mesa civilizada, por exemplo.

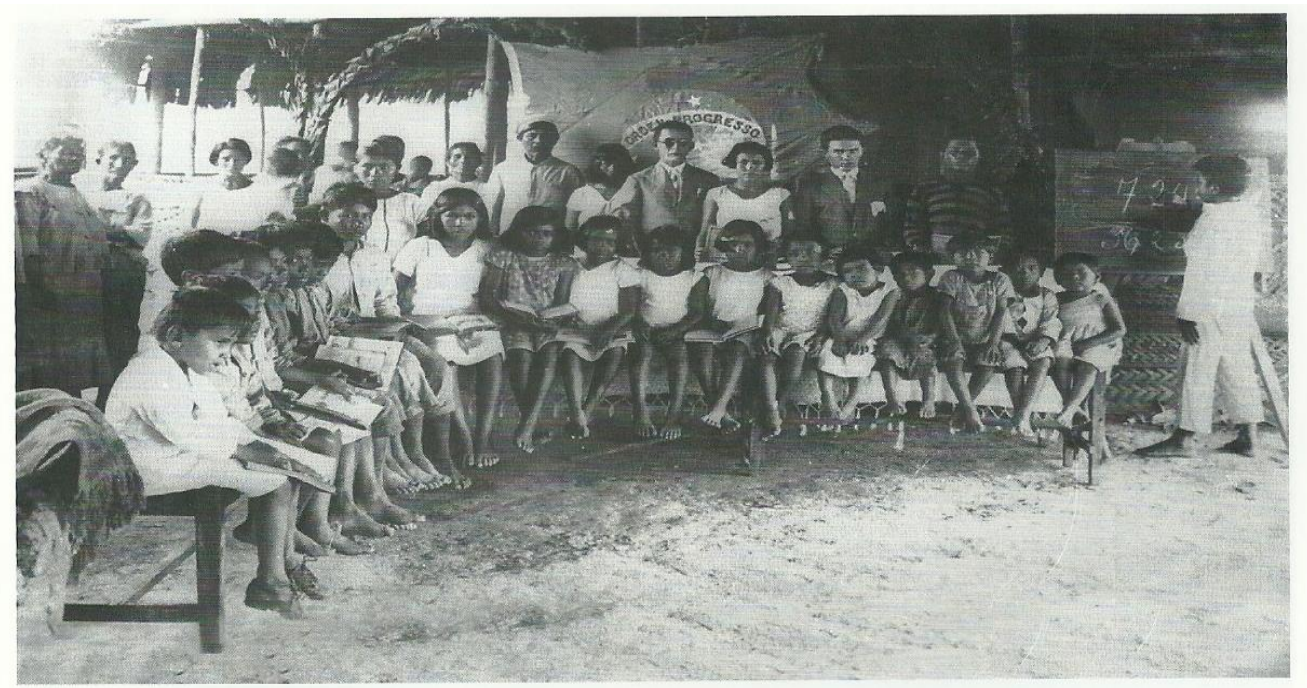

Posto indígena do lago da Josefa - índios Mura na escola indígena "Felipe Camarão" (SPI - Relatório anual da IR1, 1930-31, p. 45, foto Anastácio Queiroz, acervo do Museu do Índio). Negativo produzido por João Domingos Lamônica

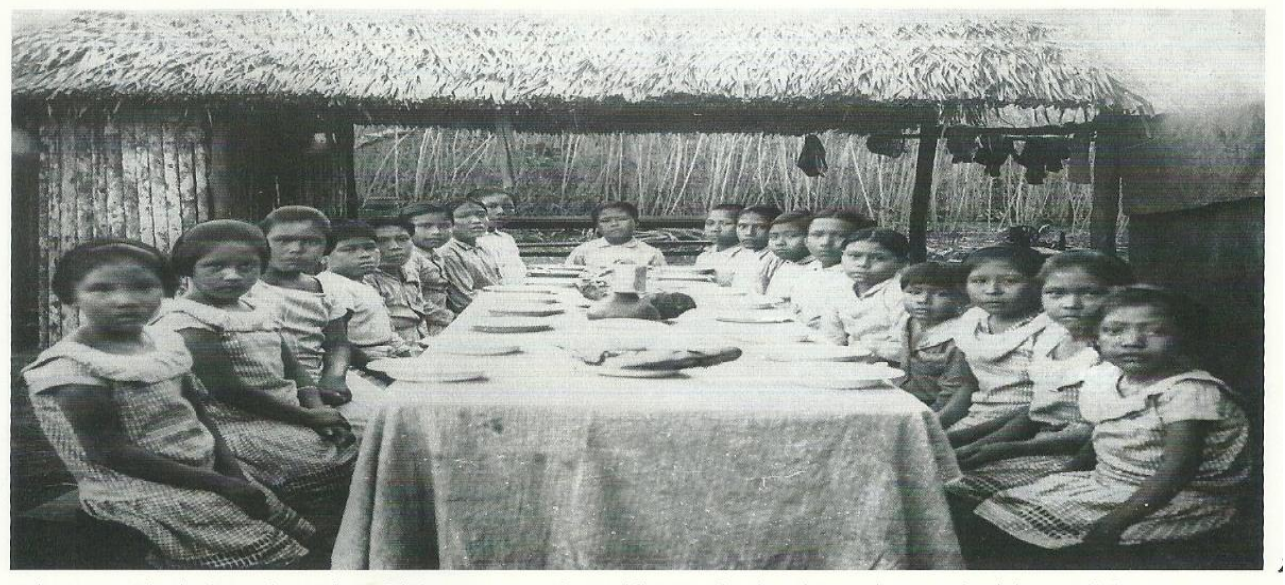

Crianças Parintintin na hora da refeição, no posto de pacificação do rio Ipixuna (SPI - Relatório anual da IR1, 1927. p. 44, acervo do Museu do índio). Negativo produzido por João Domingos Lamônica.

As imagens acima, referidas aos índios Parintintin, refletem a perspectiva/expectativa do SPI, isto é, índios sendo "educados" na educação formal e 
doméstica; índios nas roças, nas hortas. Não se tem o registro de imagens dos índios em disputas por castanhais com os comerciantes brancos.

As imagens mascaram um grande quadro de dominação, seja por meio da disciplina, ao molde skinneriano ${ }^{68}$, das cadeiras postas em fileiras nas escolas de formação, onde cada indígena se conforma com o seu lugar, seja pela introdução de outros fluxos culturais como o rádio, o gramofone tocando o hino à bandeira e, por fim, a diferença cabal entre a catequese cristã e o poder tutelar. O Mapa do Brasil substituindo a cruz.

\section{As viagens de inspeção do SPI no rio Madeira}

As viagens de inspeção do SPI aos postos do rio Madeira ocorreram nos anos de 1933 a 1943. Neste período, três relatórios põem a nu as atrocidades e o processo de esbulho dos territórios indígenas, capitaneado por Garcia de Freitas, com o apoio dos seringalistas e comerciantes da região.

Os dois primeiros relatórios, de autoria de Alfredo José da Silva, servidor do SPI, trouxeram uma visão trágica, apontando que os povos indígenas do Madeira se encontravam em abandono.

Quanto aos Parintintin e índios Mura, os primeiros, tenho a lamentar a grande miséria de que são vítimas, por terem saído das selvas para o seio dos civilizados. Seria muitíssimo melhor se lhes permanecessem no seu estado primitivo, livre da ganância do homem civilizado, hoje sem o auxílio do governo, eles tem sofrido as intempéries da natureza e a pressão do homem civilizado, escravizados pelo medo, aos serviços mais grosseiros, expostos à nudez. É certo que nas selvas não andavam vestidos, mas tinham todo o tempo para procurar o que comer. Finalmente viviam livres do senhor branco. Fui encontrar em completa miséria, onde são escravos, os índios Parintintin que sob o rótulo de bem feitores, existem, criaturas que mui superficialmente lhes protegem. Essa proteção consiste em tirá-los de casa as pessoas pobres para escravizá-los e explorá-los escandalosamente, nos serviços de campo, como acontecem aos que habitam nas Três Casas e Pádua. No médio rio Maicy, onde os mesmos são extratores de balata e castanha, ganhando $10 \%$ do seu trabalho pelo senhor comerciante Aristides Ferreira Bicho. E, ainda mais contou-me que, um tal de Mariano Alecrim Lopes, também tem explorado não somente dessa forma, como também por motivo fútil, deu uma surra numa índia de nome Borobê, mãe do índio a qual ficou doente ${ }^{69}$.

Conforme já aludido, a falta de recursos financeiros impossibilitou o término do empreendimento pacificador nos termos de Nimuendaju. Desta forma, os Parintintin

\footnotetext{
${ }^{68} \mathrm{Na}$ teoria skinneana (2003) a aprendizagem só funciona se o comportamento do ser humano for estimulado ou reprimido. A repetição mecânica deve ser incentivada, pois esta leva à memorização, e assim, ao aprendizado. Foi dessa forma que o SPI utilizou o sistema escolar nas aldeias Kagwahiva no período de pacificação.

${ }^{69}$ SILVA, José Alfredo da. Relatório encaminhado ao Inspetor Regional do Ministério do Trabalho, Indústria e Comércio e encarregado do Serviço de Proteção aos Índios no Amazonas e Acre, s/p, 1936.
} 
e outros grupos Kagwahiva sofreram as consequências nefastas da exploração econômica desmedida, tornando-se alvos fáceis às investidas dos seringalistas.

O relatório de Silva evidencia que as atitudes e as práticas de ação presentes nos regimentos do SPI não condiziam com as práticas cotidianas dos encarregados pelos postos indígenas. As denúncias de escravidão e exploração da força de trabalho indígena revelam que muitos colonos comerciantes forçavam o endividamento dos grupos indígenas e, nesse sentido, não se percebem significativas diferenças entre a atuação dos servidores e a dos comerciantes. Leal ${ }^{70}$ observou não existir descontinuidade na prática dos agentes, visto que os mesmos mantêm, há pelo menos oitenta anos, o mesmo padrão de relações políticas com os coletivos humanos no rio Madeira.

Nesse emaranhado conflituoso, duas formas de resistência indígena são registradas por Silva. A primeira, o afastamento de alguns grupos para as cabeceiras dos rios. A segunda, as tentativas de denúncia por parte dos Parintintin ao próprio SPI, objetivando o afastamento dos exploradores das terras indígenas. Particularmente no que se refere a esta segunda forma de resistência, temos informações mais fartas, coletadas do relatório do próprio Silva ${ }^{71}$, por exemplo, a denúncia contra Alecrim Lopes, relacionada à compra ilegal das terras indígenas dos Parintintin e dos Pirahã. No relatório que fez no ano de 1939, Silva denunciou mais uma vez os desmandos de Garcia de Freitas.

Encontrei os índios da tribo principal do rio Ipixuna, que são os célebres Parintintin, em tapiris insalubres, bastante de tuberculose, impaludismo e gripe, num verdadeiro estado de angústias e comiseração. Dias antes de minha chegada, um formidável incêndio havia devorado todas as suas habitações, extinguindo-lhes quase todo o material de trabalho, causando-lhes, assim, enormes prejuízos. É lamentável, a situação desses seres humanos, afastados da sociedade civilizada, desprotegidos do destino e sem recursos médicos apropriados. (...) Assim que cheguei ao Povo Indígena, proibi a entrada de regatões nos seus pontos habituais, assim como a entrada de civilizados gananciosos, que reunidos em turmas, subiam o rio Ipixuna, no intuito de explorar as terras que são patrimônio ilimitado do silvícola, carregando todo o produto que a este pode servir de amparo. Sanei, graças a Deus, embora por algum tempo, o grande flagelo; contudo, tenho ainda que vencer outra dificuldade nos rios Marmelos e Maici. No primeiro, acima de sua foz, duas horas de viagem, em canoa, acha-se localizada a maloca dos índios "Turás", ponto de comerciantes gananciosos do rio Madeira, os quais pretendem apossar-se de um castanhal, pertencente a tribo dos mencionados indígenas, castanhal esse de onde a tribo extrai os

\footnotetext{
${ }^{70}$ LEAL, Davi Avelino. Direitos e processos diferenciados de territorialização: os conflitos pelo uso dos recursos naturais no rio Madeira (1861-1932). Tese (Doutoramento em Sociedade e Cultura na Amazônia) Universidade Federal do Amazonas. 2013.

${ }^{71}$ SILVA, José Alfredo da. Relatório encaminhado ao Inspetor Regional do Ministério do Trabalho, Indústria e Comércio e encarregado do Serviço de Proteção aos Índios no Amazonas e Acre, s/p, 1936.
} 
produtos necessários à sua subsistência. O indivíduo de nome José Alecrim Lopes, possuidor de alguns centos de reis, que a ganância lhe proporcionou, impediu, por meio violentos, que os índios fizessem a safra da castanha, ali, o ano passado, e, este ano, tentou expulsá-los do castanhal de sua propriedade, cujo terreno foi demarcado, em abril de 1921, pelo Major Manoel Silvestre do Amarante, assim que os aborígines comunicara-me este fato, declarando que o referido terreno foi vendido a José Alecrim Lopes pelo ex-encarregado do Posto Indígena, José Garcia de Freitas, inimigo e escravizador dos laboriosos "Parintintins", protestei, imediatamente, contra esta venda ilícita, por oficio que dirigi, a 10 de agosto, ao indivíduo Alecrim. (...) O exfuncionário José Garcia de Freitas, ao princípio deste ano, mandou um emissário a este posto para revolucionar e atacar os índios "Diarrus", no alto Maici, resultou de tal arbitrariedade quatro mortes, sendo de uma mulher, e dois homens, da tribo dos "Diarrús", e a de outro homem, da tribo dos "Parintintins". Este fato foi ocasionado pela reação que os "Diarrús" opuzeram ao cativeiro que José Garcia de Freitas, lhes impunha, no qual eram constantemente surrados e, algumas vezes, até mortos por espancamentos. Todos os civilizados desta e daquela zona são conhecedores de tão tristes ocorrências, não desconhecendo, também, a venda ilícita das terras dos "Turas", feitas por José Garcia, o qual já vendeu, também, do mesmo modo, outras propriedades dos índios "Diarrús ${ }^{72 "}$ ".

Ora, como podemos refletir sobre o desafio de construir uma antropologia histórica Kagwahiva? Assinala Salhins, não é apenas saber como os eventos são ordenados pela cultura e sim como, nesse processo, a cultura é reordenada. Neste sentido, o confronto de duas culturas constitui tipos muito comuns de mudanças históricas.

Continua o autor:

De fato, as afirmações que derivo dos processos históricos não requerem condições de contato intercultural. Elas supõem apenas um mundo onde as pessoas agem de formas distintas e de acordo com suas respectivas situações como seres sociais, condições estas tão comuns à ação numa dada sociedade como à interação em sociedades distintas ${ }^{73}$.

Se os processos e as situações históricas são esvaziadas dos contextos interculturais, o que resta dos eventos, das histórias, da própria História? As situações históricas em que os Tupi-Kagwahiva estavam envolvidos nos estimulam às seguintes indagações: Em que momento da história os Jiahui e os Parintintin reordenaram a cultura e a transformaram em uma forma de resistência? Em qual situação histórica estes grupos

\footnotetext{
72 SILVA, José Alfredo da. Relatório encaminhado pelo encarregado do posto indígena do Ipixuna referentes às atividades do mesmo ano. (Filme 32, planilha 389), Rio de Janeiro: Museu do Índio, s/p, 1939.
}

${ }^{73}$ SALHINS, Marshall. Metáforas históricas e realidades míticas: estrutura nos primórdios da história do reino das ilhas Sandwich. Rio de janeiro: Jorge Zahar, p.17, 2008. 
refletiram sobre as condições servis nas quais se encontravam, voltando a assumir posições guerreiras em defesa de seu território e da manutenção de suas tradições como coletivos humanos diferenciados dos regionais?

Se olharmos atentamente para as imagens alegóricas descritas no relatório de Silva de 1939, quatro cenas emblemáticas (as doenças, o território ilimitado, o regatão e o SPI) estão presentes no cotidiano Kagwahiva até o final dos anos de 1980. Tais imagens, pensadas como dramas sociais, consubstanciaram as formas de resistência e permitiram aos Kagwahiva a reinvenção dentro de um processo histórico de usurpação do próprio território.

As doenças tornaram-se uma realidade no cotidiano Kagwahiva. De fato, desde aquela viagem aos seringais do rio Madeira, ocorrida em 1925, em companhia de Garcia de Freitas e Manoel Lobo, os Kagwahiva contraíram doenças que ceifaram a vida de muitos Parintintin. Com a presença de colonos nos Postos Indígenas, os Jiahui também sofreram as consequências das doenças, como atestou Silva no relatório do SPI 1936.

No final dos anos 1980, os Parintintin se encontravam reduzidos. Eram em torno de 149 indígenas distribuídos em lugares diferentes, dentro dos limites do território tradicional. Doze moravam no distrito de Calama. Cinco estavam misturados com a frente de atração Uru-eu-wau-wau. Alguns outros moravam nas periferias de Manaus. Os Jiahui foram incorporados aos Tenharin e somavam apenas doze pessoas.

Os Parintintin, os Jiahui e os Tenharin sofreram com as epidemias trazidas pelos processos de territorialização iniciados com a economia do extrativismo, com a mineração, com as rodovias e as frentes de expansão agropecuária. Segundo Amauri Tenharin, "se as doenças não tivessem vindo até nós, hoje possivelmente seriamos entre 30 a 40 mil indígenas" (informação verbal ${ }^{74}$ ). José Carlos Levinho ressalta que o SPI tinha conhecimento de que o contato não era apenas o fim das hostilidades entre indígenas e brancos, pois “o número de vítimas não se comparava às epidemias, que reduziram muitos povos indígenas em um punhado de grupos domésticos ${ }^{75}$ \%.

A segunda cena, a ideia do "patrimônio ilimitado", presente no relatório de Silva, vislumbra a conivência do órgão indigenista com o consórcio de assassinos que adentrava nas terras indígenas. A representação do patrimônio ilimitado/limitado serviu, posteriormente, para dividir grandes territórios em reservas indígenas e, ao mesmo tempo,

\footnotetext{
${ }^{74}$ Narrativa coletada na aldeia Marmelo III em agosto de 2016.

${ }^{75}$ LEVINHO, José Carlos. Parintintin. Série: Índios do Brasil. Brasília, p.1-15, 1990.
} 
reclassificar grupos domésticos em grupos genéricos, renomeando suas autodenominações como Tenharin, Parintintin, Urueu-wau-wau e outros.

A terceira imagem é a do "Regatão", percorrendo os rios da Amazônia, usurpando os territórios indígenas Kagwahiva. É uma imagem semelhante àquela descrita por Roberto Cardoso de Oliveira ${ }^{76}$ a respeito dos Ticuna, quando expulsos das terras altas por caucheiros peruanos, vindo a fixar-se no Solimões, onde foram incorporados ao meio pelas empresas seringalistas. Igualmente, Roque Laraia e Roberto DaMatta ${ }^{77}$, ao refletirem sobre as condições sociais nas quais se encontravam os povos indígenas no rio Tocantins, no século XX, informam que dois destinos aguardavam aqueles indígenas: ou continuariam marginalizados ante o cenário da economia extrativista (no caso, especificamente os Surui e, posteriormente, os Assurini), ou colocar-se-iam na condição precária de castanheiros independentes, como os Gaviões.

$\mathrm{Na}$ perspectiva de Sahlins, "a história é organizada por estruturas de significação ${ }^{78}$ ". Quando é que as situações históricas extrapolam o campo das estruturas de significação? Como podemos refletir no que concerne às memórias das doenças? E quanto ao patrimônio ilimitado, transformado em reservas? Como podemos compreender a imagem do regatão sendo ressignificada contemporaneamente a partir da personagem emblemática do "atravessador" de castanha e óleo de copaíba?

Talvez as situações históricas vivenciadas pelos Kagwahiva não sejam iguais à história havaiana, que se repete entre o mito e o evento. Em outro sentido, as situações históricas podem ser pensadas como processos transformacionais, no momento em que os agentes sociais (os Kagwahiva) concebem uma reflexão acerca da defesa do território, da manutenção da cultura. Ao fazerem isso, elaboram uma autoconsciência cultural para pensar as relações estabelecidas com o branco, relações extremamente desiguais e predatórias. A autoconsciência cultural como que reascende as antigas posições guerreiras Kagwahiva, pela defesa de suas cosmologias como um elo diferenciador entre os Kagwahiva e os outros, os não Kagwahiva.

No entanto, as imagens contidas nesse espelho, que é fosco, não são apenas as do índice de mortandade cristalizadas nas ações do SPI. A última imagem é o SPI. Os efeitos

\footnotetext{
${ }^{76}$ CARDOSO DE OLIVEIRA, Roberto. O índio e o mundo dos brancos: a situação dos Tükúna do alto Solimões. São Paulo, Difusão Europeia do Livro, Coleção Corpo e Alma do Brasil, 1964.

${ }^{77}$ LARAIA, Roque de Barros; MATTA, Roberto da. Índios e Castanheiros: a empresa extrativista e os índios no médio Tocantins. Rio de Janeiro: Paz e Terra, 1978.

${ }^{78}$ SALHINS, Marshall. Metáforas históricas e realidades míticas: estrutura nos primórdios da história do reino das ilhas Sandwich. Rio de janeiro: Jorge Zahar, p.27, 2008.
} 
das ações indigenistas são transmutados para o contemporâneo e reconfigurados, materializados na Fundação Nacional do Índio - FUNAI. Dentro deste quadro alegórico, os funcionários foram contratados, na maioria dos casos, às beiradas das cidades que se formaram dentro das terras indígenas (Humaitá, por exemplo). Assim, podemos dizer, sem exageros, que tais pessoas eram inexperientes e ineptas para o exercício das atividades que lhes foram confiadas. No mais, suas experiências nos tratos com indígenas se resumiam à participação ou envolvimento em algum conflito travado entre regionais e indígenas ${ }^{79}$. O reflexo deste espelho fosco evidenciou que o SPI mostrou-se muito mais preocupado com sua própria sobrevivência do que com o resguardo dos inúmeros grupos indígenas sob sua tutela, ao incentivar formas de desenvolvimento e atividades econômicas sustentadas com a mão de obra indígena, com o intuito de alcançar autonomia financeira nas suas unidades administrativas.

Parafraseando Souza Lima, qual a necessidade de repensarmos esta forma de Poder, talvez tida como superada? O que ainda resta sobre esta forma de regime tutelar ${ }^{80}$, representado pela agência indigenista para escrutinarmos? Se levarmos em consideração que os direitos que foram conquistados a duras penas durante todo o século XX estão sofrendo atualmente um franco ataque, consubstanciado no desmonte da agência estatal voltada para a questão indígena, significando um verdadeiro retrocesso nas leis indigenistas, veremos que tal discussão está longe do esgotamento.

As raízes do regime tutelar foram tão profundas entre os Tupi-Kagwahiva que fazem parte do cotidiano dos mesmos. A supressão das músicas nativas e o modelo disciplinador dos corpos foi, ao longo do tempo, somada a outras formas simbólicas de interação social. Entre os Parintintin, a festa Irerua foi abandonada por décadas. Em seu lugar passou-se a festejar dois santos cristãos. A língua Kagwahiva também sofreu com as investidas colonizadoras, sendo substituída gradualmente pelo português. Nas palavras de M. Parintintin ${ }^{81}$ ao referir-se à perda do domínio do idioma Kagwahiva: "Foi roubado de nós! (informação verbal)". De fato, atualmente apenas $30 \%$ do povo Parintintin consegue se expressar no idioma nativo.

\footnotetext{
${ }^{79}$ LEVINHO, José Carlos. Parintintin. Série: Índios do Brasil. Brasília, p.1-15, 1990.

${ }^{80}$ Segundo Oliveira $(2016$, p.200) "Estabelecer a tutela sobre os "índios" era exercer uma função de mediação intercultural e política, disciplinadora e necessária para a convivência entre os dois lados, pacificando a região como um todo, regularizando o mercado de terras, e criando condições para o chamado desenvolvimento econômico".

${ }^{81}$ Narrativa coletada em outubro de 2018 na aldeia Pupunha.
} 
A presença do SPI nos afluentes do rio Madeira caracterizou-se como o primeiro processo de territorialização que afetou os povos Kagwahiva. Nas décadas seguintes, esses processos sofisticaram-se. A mineração nas terras indígenas, as aberturas de rodovias no interior das terras indígenas, bem como a penetração da frente agropecuária nos territórios Kagwahiva, representaram a transmutação destes processos. Nesse sentido, o Estado exerceu seu papel ao lançar mão de processos de inculcação de seus preceitos, refletidos na unidade de crença e pertencimento, "lembrança sempre da intencional erradicação dos costumes nativos, da vivência do tempo e do espaço cercado pelo grande cerco de $\mathrm{Paz}^{82}$ ". É interessante frisar que as imagens do passado do povo Kagwahiva, que inevitavelmente envolvem todos os conflitos e embates originados nos processos de territorialização orquestrados pelo poder tutelar, serviram, na contemporaneidade, como estratégias de resistência indígena. Tais imagens rememorizadas no cotidiano dos grupos Kagwahiva foram, de certa forma, práticas de luta Kagwahiva, uma espécie de "pacificação do branco", táticas de defesa do território. Não por acaso, as formas de resistência dos povos Kagwahiva não mobilizam ações apenas no nível micro, mas antes extrapolam fronteiras nacionais, indigenizando a esfera pública.

Data de submissão: 28/08/2020

Data de aceite: 05/02/2021

\footnotetext{
${ }^{82}$ SOUZA LIMA, Antônio Carlos de. Um grande Cerco de Paz: poder tutelar, indianidade e formação
} do Estado no Brasil. Rio de Janeiro: Vozes, p.310, 1995. 
Referências

Fontes consultadas: Relatórios do Serviço de Proteção ao Índio no período de 1925 a 1940.

FREITAS, José Garcia de. Relatório encaminhado ao inspector Bento Pereira de Lemos referente ás atividades da IR1 no exercicio de 1930. (filme 33, planiha 396, pp02-12), Rio de Janeiro, Museu do Indio, 1930.

LEMOS, Bento Martins Pereira de. Relatório do Inspetor referente aos trabalhos realizados nos exercícios de 1930 e 1931, na Inspectoria do Amazonas e Acre. Acervo do SPI/Museu do Índio, Microfilme 33, Planilha 396.

LEMOS, Bento Martins Pereira de. Relatório encaminhado ao Diretor do SPI, Sr. Dr. José Bezerra Cavalcante. Referente aos serviços da IR1 nos exercícios de 1925, p.20 Rio de Janeiro, Museu do Índio.

LEMOS, Bento Martins Pereira de. Relatório encaminhado ao Diretor do SPI, Sr. Dr. José Bezerra Cavalcante. Referente aos serviços da IR1 nos exercícios de 1925 (filme 33, planilha 396, p. 2-44); 1928 (filme 33, planilha 396, p-4-24); 1930 (filme 33, planilha 396, p.02- 12), Rio de Janeiro, Museu do Índio.

LEMOS, Bento Martins Pereira de. Relatório encaminhado ao Diretor do SPI referentes as atividades da IR1 nos exercícios de 1931-1932. Índios Mura, Mundurucu e Parintintin. (filme 379, fotogramas 106-112), Rio de Janeiro: Museu do Índio.

LEMOS, Bento Martins Pereira de. Carta encaminhada ao Gal. Rondon sobre a pacificação dos Parintintin. Filme 389, fotograma 0887-0889, Rio de Janeiro: Museu do Índio.

SILVA, José Alfredo da. Relatório encaminhado ao Inspetor Regional do Ministério do Trabalho, Indústria e Comércio e encarregado do Serviço de Proteção aos Índios no Amazonas e Acre. 1936.

SILVA, José Alfredo da. Relatório encaminhado pelo encarregado do posto indígena do Ipixuna referentes às atividades do mesmo ano. (filme 32, planilha 389), Rio de Janeiro: Museu do Índio, 1939.

BARRANCAS, Francisco Pereira. Relatório da primeira expedição ao rio Madeira. Realizada de 05 Janeiro á 22 de Março de 1941. Filme 32, planilha 389. Rio de Janeiro: Museu do Índio.

Referências Bibliográficas

BOURDIEU. Pierre. O poder simbólico. Lisboa: DIFEL, 1989.

BOURDIEU. Pierre. Esprits d'état. genèse et structure du champ bureaucratique. Actes de la Recherche en Sciences Sociales, v. 96, n. 96-97, p. 49-62, 1993

BOURDIEU. Pierre. Coisas ditas. Petrópolis: Vozes, 2002.

BOURDIEU. Pierre. Coisas Ditas. São Paulo: Brasiliense, 2004. 
BOURDIEU. Pierre. Sobre o Estado. São Paulo: Cia das Letras. 2014.

BENTHAM, Jeremy. O panótpico. Belo Horizonte: Autentica Editora, 2019

FREIRE, Carlos A. da Rocha. O SPI na Amazônia: política indigenista e conflitos regionais (1910-1932). Rio de Janeiro: Museu do Índio, 2009.

KRACKE.Waud H. structure of interethnic contacts between the Parintintin and brazilian society on Madeira river. The University of Chicago.1967.

KRACKE, Waud e LEVINHO, Carlos. A dinâmica e a psicodinâmica de uma sociedade em movimento ou sociedade móvel cercada. Trabalho apresentado na Reunião Brasileira de Antropologia, no GT- Questões da etnologia indígena na América do Sul. Salvador, 1996.

GONDIM, Joaquim. A pacificação dos Parintintin: Koró de Uirapá. Manaus: edições do Governo do Estado, 1925, 2001.

LAHIRE, Bernad. A fabricação social dos indivíduos: quadros, modalidades, tempos e efeitos de socialização. Educ. Pesqui. São Paulo, v. 41, n. especial, p. 1393-1404, dez., 2015.

LARAIA, Roque de Barros; MATTA, Roberto da. Índios e Castanheiros: a empresa extrativista e os índios no médio Tocantins. Rio de Janeiro: Paz e Terra, 1978.

LEAL, Davi Avelino. Direitos e processos diferenciados de territorialização: os conflitos pelo uso dos recursos naturais no rio Madeira (1861-1932). Tese (Doutoramento em Sociedade e Cultura na Amazônia) Universidade Federal do Amazonas. 2013.

NIMUENDAJU, Curt. As tribos do Alto Madeira. Textos Indigenistas. São Paulo: Loyola, 1982.

NIMUENDAJU, Curt. Os índios Parintintin do rio Madeira. Jounal de la Société des Americanistes de Paris. p. 201-278, 1924.

MENENDEZ, Miguel.Uma Contribuição para o Estudo dos Tupi Centrais. (Tese de Doutorado). FFLCH-USP, 1989.

NUNES PEREIRA, Manoel. Moronguêtá: um decameron indígena (v 2). Rio de Janeiro: Ed. Civilização Brasileira. 1980.

MELO, Joaquim. A política indigenista no Amazonas. Manaus: edições do Governo do Estado, 2009.

OLIVEIRA, Roberto Cardoso de. O índio e o mundo dos brancos: a situação dos Tükúna do alto Solimões. São Paulo, Difusão Europeia do Livro, Coleção Corpo e Alma do Brasil, 1964.

OLIVEIRA FILHO, João Pacheco de. Ensaios de Antropologia Histórica. Rio de Janeiro: Editora da UFRJ, 1999. 
OLIVEIRA FILHO, João Pacheco de. O nascimento do Brasil e outros ensaios: "pacificação". Regime tutelar e formação de alteridades. Rio de Janeiro: Contra Capa, 2016.

PEGGION, Edmundo. Relações em perpétuo desequilíbrio: A organização dualista dos povos Kagwahiva da Amazônia. São Paulo: Annablume, 2011.

PEGGION, Edmundo. Brancos e Índios no Rio Madeira: 1850-1950. Contato e Identidade Étnica. Monografia de Bacharelado em Ciências Sociais. Universidade Estadual Paulista/Campus Araraquara. São Paulo, 1992.

PEGGION, Edmundo. Relatório de identificação e delimitação da Terra Indígena Jiahui no município de Humaitá-AM. Fundação Nacional do Indio /FUNAI, 1999/2000.

SAHLINS, Marshall. Metáforas históricas e realidades míticas. Rio de Janeiro: Jorge Zahar, 2008.

SOUZA LIMA, Antônio Carlos de. Um grande Cerco de Paz: poder tutelar, indianidade e formação do Estado no Brasil. Rio de Janeiro: Vozes, 1995.

SKINNER, Burrrhus Frederic. (1972). Tecnologia do ensino. (Rodolpho Azzi, Trad.). São Paulo: Herder, Ed. da universidade São Paulo, 1972. 